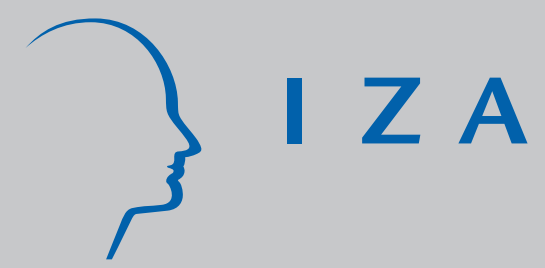

IZA DP No. 9372

Post-Secondary Education and Information on Labor Market Prospects:

A Randomized Field Experiment

Sari Pekkala Kerr

Tuomas Pekkarinen

Matti Sarvimäki

Roope Uusitalo

September 2015 


\title{
Post-Secondary Education and Information on Labor Market Prospects: A Randomized Field Experiment
}

\author{
Sari Pekkala Kerr \\ Wellesley College \\ Tuomas Pekkarinen \\ Aalto University, VATT and IZA \\ Matti Sarvimäki \\ Aalto University and VATT \\ Roope Uusitalo \\ Jyväskylä University School of Business and Economics and IZA
}

Discussion Paper No. 9372
September 2015

IZA

P.O. Box 7240

53072 Bonn

Germany

Phone: $+49-228-3894-0$

Fax: +49-228-3894-180

E-mail: iza@iza.org

\begin{abstract}
Any opinions expressed here are those of the author(s) and not those of IZA. Research published in this series may include views on policy, but the institute itself takes no institutional policy positions. The IZA research network is committed to the IZA Guiding Principles of Research Integrity.

The Institute for the Study of Labor (IZA) in Bonn is a local and virtual international research center and a place of communication between science, politics and business. IZA is an independent nonprofit organization supported by Deutsche Post Foundation. The center is associated with the University of Bonn and offers a stimulating research environment through its international network, workshops and conferences, data service, project support, research visits and doctoral program. IZA engages in (i) original and internationally competitive research in all fields of labor economics, (ii) development of policy concepts, and (iii) dissemination of research results and concepts to the interested public.
\end{abstract}

IZA Discussion Papers often represent preliminary work and are circulated to encourage discussion. Citation of such a paper should account for its provisional character. A revised version may be available directly from the author. 
IZA Discussion Paper No. 9372

September 2015

\section{ABSTRACT}

\section{Post-Secondary Education and Information on Labor Market Prospects: A Randomized Field Experiment ${ }^{*}$}

We examine the impact of an information intervention offered to 97 randomly chosen high schools in Finland. Graduating students in treatment schools were surveyed and given information on the labor market prospects associated with detailed post-secondary programs. A third of the students report that the intervention led them to update their beliefs. Experimental estimates suggest that it also affected the application behavior of the least informed students. However, this group of affected students is not sufficiently large for the intervention to have an average impact on applications or enrollment.

JEL Classification: J24, 123

Keywords: education, information, earnings, randomized field experiments

Corresponding author:

Tuomas Pekkarinen

Government Institute for Economic Research (VATT)

Arkadiankatu 7

P.O.Box 1279

00101 Helsinki

Finland

E-mail: tuomas.pekkarinen@vatt.fi

\footnotetext{
${ }^{*}$ We thank the Higher Education and Innovation Network at the University of Helsinki for funding this project, the faculty of the study's participating high schools for their generous time and assistance, and the National Board of Education for their help in obtaining the register data on applications. We also thank Joseph Altonji, Marc Gurgand, Markus Jokela, Kristian Koerselman, Philip Oreopoulos, Natalia Zinovyeva and various seminar participants for helpful comments, and Hanna Ahtonen, Angela Djupsjöbacka, Janne Karkkolainen, and Kosti Takala for excellent research assistance.
} 


\section{Introduction}

The choice of how long and what to study is among the most important investment decisions that a typical person makes during her lifetime. Thus it is not surprising that many policy makers, commentators and parents worry about students' ability to make the "right" choices. Indeed, there appears to be widespread concern that many students lack information about the financial consequences of their educational choices and thus do not learn the type of skills for which there is demand in the labor market. Many governments have responded to these concerns by running schemes that aim to improve the information available to students. ${ }^{1}$

In this paper, we argue that while information interventions are likely to be cost effective - because they are very cheap - they are unlikely to have a major impact on the allocation of students into post-secondary programs. We reach this conclusion with the help of a large randomized field experiment that provided Finnish high school students accurate information about the earnings distributions, employment rates and the most common occupations associated with detailed post-secondary educational degrees. After receiving this information, roughly a third of the treatment group students report to have updated their beliefs. The intervention also affected the application and enrollment patters of those students who were the most likely to hold unrealistically positive expectations of their preferred programs. However, this group of affected students is not sufficiently large for the intervention to have a detectable average impact on applications or enrollment.

Our experiment is designed to test the hypothesis that the match of educa-

\footnotetext{
${ }^{1}$ For example, the U.S Bureau of Census provides infographics Pathways after a bachelors degree that helps to compare average lifetime earnings across different careers, see http://www.census.gov/library/infographics/pathways-series.html/
} 
tional choice and the demand for skills in the labor market can be enhanced by providing information on the population outcomes associated with alternative degrees. This hypothesis is based on earlier work showing that information interventions can have large effects on the likelihood of continuing in secondary education in developing countries (Jensen, 2010; Nguyen, 2008) and that they affect students' beliefs in the United States and the United Kingdom (McGuigan, McNally, \& Wyness, 2012; Oreopoulos \& Dunn, 2013; Wiswall \& Zafar, in press). ${ }^{2}$ However, research on the effect of information on labor market prospects on the actual educational choice at the post-secondary level is scarce. $^{3}$

In our experiment, we contacted student guidance counselors working in 97 randomly chosen Finnish high schools and offered them an information package and related lecture materials. In the 63 high schools that chose to participate, more than 3,400 students sat through an obligatory class given as a part of their standard curriculum. During the class, students listened to a presentation by the student guidance counselor on the differences in earnings and employment rates between different post-secondary degrees. They also completed a survey where they were asked about their preferences and expectations. Along with the survey, the students were given a leaflet reporting the distribution of earnings, employment rates and the most common occupations

\footnotetext{
${ }^{2}$ Earlier work has also shown that students are misinformed about the true costs of higher education (Hoxby \& Avery, 2013) and that providing accurate information on those costs can influence enrollment (Bettinger, Long, Oreopoulos, \& Sanbonmatsu, 2012; Hoxby \& Turner, 2013). Furthermore survey evidence suggests that the earnings expectations of university students are inaccurate (Betts, 1996; Carvajal et al., 2000; Dominitz \& Manski, 1996; Brunello, Lucifora, \& Winter-Ebmer, 2004).

${ }^{3}$ Only one contemporaneous study by Hastings, Neilson, and Zimmerman (2015) examines the effect of providing information on earnings prospects about actual college choice. Their experiment is executed through an online survey to randomly selected student aid applicants in Chile immediately before college choice. In contrast, our intervention is performed in a class setting for high school seniors several months before the application deadline. Despite these differences, their results are quite similar to ours.
} 
among the current population of 30-34 year old persons by 104 most common post-secondary degrees. Furthermore, they were given the supplementary material at the end of the class, so that they could further consult it at home. The experiment was implemented 5-6 months before the students applied to post-secondary programs.

Finnish university system provides a particularly informative setting for our experiment, because students apply directly to major subjects (including professional degrees such as medicine and law). Thus the choices that we observe are closely connected with the education that the students will have when they enter the labor market. The universities choose their students based on transparent and uniform criteria which are based solely on the credits derived from the national final high school exam and from the university's own entrance examination. The importance of the entry exams - which are typically based on material not covered in high school - means that the students participating in our intervention have not yet substantially limited their choice set of post-secondary degrees. In particular, pre-intervention grades or any other kind of assessment by their high school teachers are not used as admission criteria. Furthermore, credit constraints are unlikely to complicate our analysis, because Finnish universities do not charge tuition fees and the government offers generous subsidies to students who gain entry to university. In short, we examine the impacts of the intervention on the relevant educational choices in a setting that is transparent, flexible and relatively simple.

Another advantage of the Finnish context is that we can use the national application registry to evaluate the impact of the intervention. These data cover all applications to Finnish universities and polytechnics and allow us to study the effects separately on applications and final enrollments. Access to register data also means that we avoid attrition problems and obtain high 
statistical power. Furthermore, we do not need to convince the control schools to be a part of the experiment without receiving any of the potential benefits. These data also cover several years so that we can control for the baseline educational choices at the school level in our empirical analysis.

Our experimental results show that, on average, the information intervention did not affect the likelihood of being enrolled in a post-secondary program or the type of programs where the students were enrolled. Furthermore, the application patterns among students graduating from the treatment and control school are indistinguishable from each other. The point estimates are close to zero and sufficiently precise to rule out economically significant effects.

In order to understand why the intervention had little average impact, we turn to the survey data collected as part of the experiment. Importantly, these data reveal similar belief updating as has been documented in the previous literature. Roughly a third of the respondents in our survey declared that they were surprised about the labor market prospects associated with their most likely choice of post-secondary education. Moreover, among the students who allowed us to link their survey answers to the application register, we find that this belief updating was correlated with their later choices: those who had been negatively surprised were more likely to change the field that they actually applied to than the rest of the treatment school students. We interpret these findings as evidence on the intervention conveying information to the students.

The survey results also suggest that the intervention may have affected the behavior of the subgroup of students who were disappointed about the labor market prospects of their intended field. We investigate this possibility with linked survey-register data. Using information available in the application register for the full student population - demographics, subjects taken in 
the national matriculation exam and school characteristics - we predict the likelihood of being negatively surprised about earnings in the initial program of choice. We then estimate the treatment effects for subgroups that differ in this predicted likelihood. The results suggest that the students who were most likely to be negatively surprised started to apply to programs associated with higher earnings. However, this subgroup is too small to significantly affect the average treatment effect estimates.

Finally, we argue that the intervention provided relevant information. The differences in average earnings across graduates from different fields are nearly as large in Finland as the differences reported by Altonji, Blom, and Meghir (2012) for the United States. Furthermore, Kirkebøen, Leuven, and Mogstad (2014) find that choice of field is potentially as important as the decision to enroll in college in Norway. Given the similarity of the Norwegian and Finnish labor markets, this suggests that the field of study has a major impact on earnings. Furthermore, our subsample and survey results suggest that the control group was unlikely to receive similar information through other channels. This interpretation is also supported by the fact that such information is not publicly available but has to be acquired from Statistics Finland with a significant financial and effort costs.

The rest of the paper is organized as follows. In the following two sections we describe the institutional context and the information intervention. We then discuss the findings from the survey conducted among the students in our treatment schools. The fifth section discusses the applications register and our estimation methods, and reports the results of the experiment. Section 6 concludes. 


\section{Institutional setting}

Our intervention was timed to affect the information set of students who were making their post-secondary education choices, i.e. soon to be graduating high school seniors. In Finland, these choices are made at the end of the upper secondary school, typically at the age of 18-19. In this section, we describe the main features of the Finnish educational system and the importance of post-secondary educational choices in the Finnish context.

\subsection{Context: Finnish upper secondary school graduates}

Figure 1 describes the main features of the Finnish education system. Compulsory schooling starts at age seven and lasts for nine years. More than $90 \%$ of the cohort continues to the three-year non-compulsory upper secondary school which is divided into two tracks: general upper secondary schools and upper secondary vocational schools. Our intervention targeted students in the general upper secondary schools. Roughly half of the students who continue to upper secondary school choose the general track, which is more academic in content and is the main channel through which students continue to postsecondary education. ${ }^{4}$ Henceforth, we refer to the general upper secondary schools as simply "high schools".

The three-year high school concludes with a national matriculation examination which provides the general eligibility for university studies. It consists of four compulsory exams: mother tongue (either Finnish or Swedish), the second national language (Finnish or Swedish), one foreign language, and either a mathematics or a combined science and humanities exam. In addition

\footnotetext{
${ }^{4}$ Graduates with tertiary vocational degrees can also apply to universities. However, just $5 \%$ of the university students hold only vocational degrees. Students holding only a general upper secondary school degree make up $83 \%$ of the Finnish university students.
} 
students can take as many voluntary exams as they wish. The examination is national and graded externally by a centralized examination board. The results are standardized to be comparable across years. The exams are held each spring and autumn during a two-week period.

\subsection{Applying to post-secondary education}

After completing the matriculation exam, the graduating students can file applications to post-secondary education. Typically around $75 \%$ of students apply the same year they graduate from high school. The Finnish tertiary education system consists of two kinds of institutions: universities and polytechnics. Universities focus on scientific research and education and have the right to award advanced degrees. Polytechnics concentrate on advanced vocational education. The prospective students apply directly to the specific degree program, and switching programs after entering is difficult. ${ }^{5}$ Students typically obtain their final (bachelor or masters) degree from their initial program.

The admission system is centralized, but most institutions base their admission on a combination of entrance examinations and national matriculation examination scores. The universities and polytechnics are free to design their program-specific entrance examinations. Typically these exams are based on material that is not taught in high schools. Personal essays, sports performance, letters of recommendation or extra-curricular activities are not used as admission criteria.

The applicant is allowed to apply up to seven university programs and four polytechnic programs in a given year. The programs are defined by the institution and major subject, e.g. economics at the University of Helsinki.

\footnotetext{
${ }^{5}$ In most cases, switching programs requires one to re-apply and pass the entrance examination.
} 
However, the need to prepare for entrance examination limits the number of applications in practice. The average number of applications per individual was 4.5 during the period we examine. The number of available slots per program is determined in joint negotiations between the universities and the Ministry of Education on an annual basis.

Popular programs are heavily oversubscribed and it is common that students apply several times before being admitted. In 2011, for example, only $19 \%$ of the high school graduates of that year were immediately accepted to a university and $18 \%$ to polytechnics. That is, roughly two thirds of the high school graduates did not gain admission in the first year that they tried. ${ }^{6}$ However, most high school graduates succeed in gaining admission in a few years after graduating.

Admission to a university program typically gives the right to study until the master's degree. Importantly, this practice also includes professional degrees like law and medicine. Universities are not allowed to charge tuition and the main source of funding is the state budget through the Ministry of Education. The state funding to universities is allocated on the basis of the number of targeted and completed master's and advanced degrees. This creates an incentive for the universities to attract the best available students. Students are provided generous study grants, highly subsidized accommodation and access to government guaranteed student loans. Thus credit constraints are unlikely to be important in the Finnish context.

\footnotetext{
${ }^{6}$ There is considerable variation across fields, with sciences accepting $34 \%$ of the applicants whereas small fields such as theatre and arts accept only $3 \%$ of the applicants.
} 


\subsection{Characteristics of post-secondary degrees}

Post-secondary degrees differ in the kind of labor market prospects that they provide and the kind of applicants they attract. Table 1 documents the application patterns in 2011-2013 using data discussed in detail in section 5.1. The most popular degree, nursing in polytechnics, attracts $17 \%$ of the applications and has an admission rate of only $9 \%$ despite the low average earnings of the current 30-34 year olds holding this degree. Nursing is followed in popularity by polytechnic degrees in business and engineering and university degrees in education, humanities and natural sciences.

Importantly, annual earnings vary considerably across programs. Graduates from university level medicine, law, engineering and business programs tend to earn, on average, almost twice as much as the graduates from nursing and education. Furthermore, employment prospects are positively correlated with average earnings. For example, employment rates at age 30-34 in engineering and medicine are well above 90 percent.

Of course, these earnings differences are unlikely to be solely caused by educational degrees. For example, Kirkebøen et al. (2014) find that Norwegian students select into different programs based on their comparative advantages. However, they also present compelling evidence suggesting that completing a degree in medicine, law, business or engineering has a large positive causal effect on earnings in comparison to other alternatives.

Unfortunately, the Finnish context does not lend itself to a clean identification of the impact of alternative degrees on earnings. Thus we present only a rudimentary analysis in Figure 2 by plotting the average earnings of the 30-34 old individuals currently holding the degrees against the average matriculation exam scores of the students who were enrolled in these programs 
in 2011-2013. ${ }^{7}$ The figure shows a clear positive association between matriculation exam scores and degrees' average earnings. However, it also shows that conditional on matriculation exam scores, large differences in expected earnings remain. For example, students enrolled in university level engineering and humanities programs have similar average matriculation exam scores despite the almost 20,000 euros (or 60\%) difference in their average annual earnings. Another striking example is the polytechnics engineering programs, which combine low average matriculation exam scores and relatively high acceptance rates with high earnings and employment rates. Thus it seems likely that for many students, the choice of post-secondary degree has a large impact on their future earnings.

\section{The experiment}

In this section, we describe the design and implementation of the information experiment. We start by describing how the treatment schools were selected and give background information about the student guidance counselors who implemented the intervention. We then describe the content of the information package in detail.

\subsection{Research design}

Our experiment was implemented through the standard high-school curriculum in order to use the expertise of the student career counselors and to examine an intervention that could be easily scaled up within the Finnish high-school sys-

\footnotetext{
${ }^{7}$ The average grade was calculated based on the four compulsory subjects in the high school matriculation examination: Mother tongue, and the best three grades out of (a) mathematics (long or short curriculum), (b) foreign language, (c) the second domestic language (Swedish), and (d) the best grade in the battery of tests in humanities and sciences.
} 
tem. We divided the 363 Finnish language high schools operating in mainland Finland into treatment and control groups using randomized block design by 18 provinces and the average matriculation examination grades of the schools in 2008-2010. This approach assures that we include treatment schools from all parts of the country and the achievement distribution. In total, 97 high schools were allocated into the treatment group and 266 to the control group. The details of the procedure are discussed in Appendix A, where we also show that the background characteristics of the treatment and control groups are balanced.

For each treatment school, we visited the school website to obtain the contact details of the student guidance counselors and sent them an email inviting their schools to participate. Of the 97 schools contacted, 40 responded positively and none negatively to the first invitation. The 57 schools that did not respond were contacted by email again, which resulted in 23 additional schools being recruited for the study and one refusing to participate due to the absence of student guidance counselors. The participating sample includes a total of 63 schools with altogether 5,543 students in the final year of high school. Complete survey responses were received from 59 schools by the end of $2011 .^{8}$ These 59 schools had 4,984 final year students and we received 3,437 responses to our survey. Importantly, we define the randomly chosen group of 97 schools as our treatment group irrespective of how they responded to our call.

\footnotetext{
${ }^{8}$ Four schools never returned the surveys and one conducted the intervention on the wrong cohort of students.
} 


\subsection{Student guidance counseling}

The intervention was implemented during the student guidance counselors' classes that are a mandatory part of the curriculum. ${ }^{9}$ These classes are the most natural channel through which to distribute information related to different post-secondary degrees, because one of the main tasks of the counselors is to inform students about career choices. The counselors are teachers who have taken an additional one-year of full-time university training in counseling. The pre-requisite for this training is a Master's degree in education and a teacher qualification (see Appendix A.4 for details).

Importantly, the student guidance counselors do not have access to the type of information provided by our experiment. On the contrary, our review of the counselors' occupational magazine, Opo-lehti, suggests that the presentation of each post-secondary education option is given an equal esteem regardless of their labor market prospects. Furthermore, while certain occupation-specific trade unions provide rough characterizations of typical or recommended initial wages on their websites, the kind of detailed, comparative and comprehensive information provided in our experiment is not easily available anywhere.

\subsection{The intervention}

During the fall semester of 2011, we contacted the treatment school student guidance counselors who were also responsible for the actual implementation of the information and survey sessions. We offered them instructions and quickly responded to any questions that arose during the experiment. After the intervention was implemented during the 2011 fall semester, the survey

\footnotetext{
${ }^{9}$ Finnish high schools students have to take 38 lessons, usually spread out over 3 years, in counseling.
} 
forms were returned to us and the students retained the information packages. We therefore expect the information provided to affect the application behavior from the spring of 2012 onwards.

The intervention was implemented in one 45-minute session and was structured as follows. First, the student guidance counselors were instructed to prepare a roughly 20 minute presentation providing general information on the value of education in the labor market. We provided a PowerPoint presentation along with a separate document that provided suggestions about the general message the counselors might want to convey with each slide. The slides provided information on the earnings distributions by education level and broad field, the lowest and highest earning degrees by field, information about the cost and funding of studies, and the overall acceptance probabilities and completion times for various degrees.

After giving the presentation, the counselors were asked to hand the information packages and questionnaire forms to the students, and to allow 15-20 minutes for them to fill in the questionnaires. Finally, we instructed the teachers to collect the questionnaires but let the students retain the information materials. ${ }^{10}$

The information package presented employment rates, average monthly earnings and a graph on the distribution of monthly earnings (first and ninth deciles, quartiles and median) for current 30-34 year olds holding each degree. Figure 3 illustrates the way we presented this information using a slide from the PowerPoint presentation provided to the counselors. In addition, we listed the two most common occupations and the share of graduates in these occupations for each degree. In order to keep the package at a reasonable length, we mostly

\footnotetext{
${ }^{10}$ All the materials provided to the schools, along with English translations, are available at www.aalto-econ.fi/sarvimaki.
} 
used the 3-digit level of the education classification. However, we also reported separately those 4-digit level degrees for which the average earnings differed noticeably from the 3-digit level averages. ${ }^{11}$ This criterion led us to use a classification of 41 secondary education degrees, 19 polytechnic degrees, and 44 university degrees.

\section{Survey results}

This section summarizes the main results from the survey data collected as part of the intervention. We ran the survey to acquire information on the students' aspirations, the level of information they had about the labor market prospects associated with different educational choices, and on which sources they relied for such information. Altogether 3,418 students returned the survey, corresponding to $64 \%$ of the final year students in the schools that complied with the information experiment.

\subsection{Aspirations and sources of information}

Our survey started with questions about the aspirations regarding future education. Almost everyone responded that they intended to continue their studies after high school. ${ }^{12}$ Figure 4 a shows that $55 \%$ of women and $48 \%$ of men expected to obtain a Master's degree. Roughly a quarter expected to obtain a polytechnics degree, while a fifth answered that they did not yet know.

\footnotetext{
${ }^{11}$ For example, while most of the university level engineering degrees are well-described by the 3-digit level MSc in Technology, graduates from the Industrial Management program earn significantly more and graduates from the Process Technology program significantly less than the average engineering graduate.

${ }^{12} 94 \%$ were planning to apply to post-secondary education, $0.4 \%$ said that they do not have such plans and 5\% stated that they were unsure. Furthermore, $60 \%$ stated that they planned to apply directly after finishing with the matriculation examination.
} 
Only $5 \%$ expected to enter the labor market with only a secondary degree.

We then asked the students to list up to four programs they were planning to apply to and what they considered to be important factors when making this choice. Figure $4 \mathrm{~b}$ presents the answers for the part inquiring about the importance of post-education earnings. Roughly four fifths of the students agree or strongly agree that future earnings are an important factor in their educational choice. Men place slightly more emphasis on earnings than women. However, gender differences are much clearer when asked about the other dimensions of programs. In particular, women clearly put more emphasis on whether the subject that they study is interesting and whether it leads to an interesting job. (See Appendix Figure C.1).

The survey continued with questions about how informed the students felt about labor market prospects associated with alternative degrees and where they obtained this information. Two-thirds of men and $56 \%$ of women considered themselves to be well informed. Figure $4 \mathrm{c}$ shows that the most important sources were the student guidance counselor and the internet, with parents, peers and study guides playing a smaller role.

\subsection{Belief updating}

The most important section of the survey concerned the extent to which the intervention led to belief updating. We started this section by asking students to check the average earnings and employment rates of their preferred degree from the supplementary material and to write these numbers down. The motivation for asking these questions was to make sure that the students looked at the information package. It also allowed us to check the consistency of their answers: $62 \%$ of the students provided the correct earnings and employment 
rates given their declared first choice degree.

Figure $4 d$ plots the distributions of average monthly earnings of the students' first ranked programs by gender. The figure reveals a considerable variation in the average monthly earnings of the programs where the students are planning to apply to and shows that women are planning to apply to programs that are associated with lower paid jobs than men. We then asked the students whether the average earnings and employment rates in the field that they ranked as their first choice was higher, equal to or lower than what they expected. Roughly $19 \%$ reported to be negatively surprised while $18 \%$ were positively surprised.

It is informative to examine who were the most likely to be surprised. Table 2 reports the distribution of surprises by the students' background characteristics. It shows that being negatively surprised is associated with being a woman, reporting to be poorly informed to begin with and stating that the post-education earnings are not important. In addition, surprises are correlated with several measures of academic achievement. Respondents who eventually took the advanced mathematics test in the matriculation exam are less likely to be surprised than students who did not. Furthermore, students graduating from lower quality schools - defined as the school's average matriculation grades being below median-are more likely to be surprised by the information we provided. However, the average matriculation examination scores of the students themselves do not seem to be correlated with being surprised.

Table 3 presents the surprises by the field of study. It reveals that among reasonably large university fields, students who listed business, medicine, and engineering as their first choice tended to be positively surprised, whereas those planning to apply to an education or psychology degree tended to be 
negatively surprised. Interestingly, there is a positive correlation between the fields' average earnings and the direction of surprises, suggesting that students may underestimate cross-field earnings differences.

\section{Experimental results}

This section presents the experimental results. We start with a description of the applicant register data and then present application-level and student-level analysis of the impacts of the intervention.

\subsection{Application register}

Our experimental analysis is based on data drawn from two centralized registers maintained by the Ministry of Education (HAREK and AMKOREK). These registers are used to allocate students to post-secondary programs. For each student, we observe her full set of applications, whether she attended the entrance examination, whether she was accepted into the program and whether she eventually chose to enter. In addition, the data contain the students' detailed matriculation exam grades and the name of the high school from which she graduated. We have access to this information for years 2011-2013.

The register data have several important strengths. They allow us to observe post-intervention outcomes without having to reach the students for a second round survey. Thus we avoid attrition problems that often plague experimental designs. We can also keep track of the students who did not obtain offers in 2012 and observe their application behavior in 2013. In addition, we observe the application patterns of students graduating from the control schools without having to convince these schools to be a part of the exper- 
iment. Finally, we observe the pre-intervention applications from both the treatment and control schools.

\subsection{Impact on the distribution of applications}

We start by examining the differences in the distribution of applications across programs between the treatment and control schools. Columns (1) to (4) of Table 4 report the shares of applicants at the year of graduation aggregated by field of study, treatment/control group and cohort. ${ }^{13}$ Column (5) reports odds ratios that measure how the shares of applications changed in control and treatment groups between 2011 (pre-treatment) and 2012 (post-treatment). If the odds ratio is larger than one, students graduating from treatment schools have become more likely to apply to that field than students graduating from the control schools. Hence, these odds ratios can be interpreted as differencesin-differences estimates of changes in applications behavior.

We use randomization inference to test whether the changes in the distribution of applications differ between the treatment and control schools (Fisher, 1935; Rosenbaum, 2002). ${ }^{14}$ The only statistically significant odds ratio is for the small field of architecture. Given that that these p-values do not correct for multiple inference, one would expect that one out of the 22 estimates reported in Table 4 is significant purely by chance. Furthermore, the p-value

\footnotetext{
${ }^{13}$ Appendix Table C.1 presents similar analysis for applications one year after graduation.

${ }^{14}$ This choice of inference yields correct p-values despite the potentially complex clustering structure in data. Such clustering would arise, for example, if application behavior were affected by school level factors such as peer behavior and geographical location. The issue is further amplified by the fact that several applications typically originate from the same student. Thus standard inference procedures could be severely misleading. In practice, we draw placebo random assignments $P_{s}$ using the same randomization process over schools as was used in the real intervention. We then calculate the estimate of interest, $\hat{\delta}_{P}$, for each placebo assignment and obtain an empirical c.d.f distribution $F\left(\hat{\delta}_{P}\right)$. P-values are calculated by comparing where the measured real treatment effect, $\hat{\delta}$, falls in the distribution $F\left(\hat{\delta}_{P}\right)$.
} 
for the test for homogeneous association, i.e. that all odds ratios are equal, is 0.78 . In short, we find no evidence that the intervention has a detectable effect on the overall distribution of applications.

\subsection{Impact on enrollment and application portfolios}

We now turn to examine the impact of the intervention on enrollment patterns and individual-level application portfolios. The first panel of table 5 presents estimates for the impact of the intervention on the likelihood of enrolling in any post-secondary program. The estimates correspond to $\delta$, in a differencesin-differences regression

$$
y_{i j s t}=\alpha_{j}+\beta D_{s}+\gamma D_{t}+\delta\left(D_{s} \times D_{t}\right)+\mu_{s}+\epsilon_{i j t s}
$$

where $y_{i j s t}$ is an indicator variable for student $i$ being enrolled in any program $j$ years after graduating from high school $s$ in year $t, D_{s}$ is an indicator variable for the high school being offered the intervention, and $D_{t}$ is a calendar year fixed-effect, and $\mu_{s}$ is a vector of strata fixed-effects (see Appendix A for details). We use differences-in-differences specification as a baseline, because it provides a parsimonious way to summarize our entire data. The coefficient $\beta$ measures the extent to which the treatment and control groups differed already prior to the intervention. Coefficient $\gamma$ measures the overall changes in the outcome over calendar year. Most importantly, coefficient $\delta$ measures the treatment effect. ${ }^{15}$

Columns (1) to (3) of panel A, Table 5, show that our information intervention did not have any effect on the likelihood of enrolling in a university or

\footnotetext{
${ }^{15}$ Cross-sectional estimates are presented in Appendix Table C.2, and the full differencesin-differences estimates in Appendix Tables C.3 and C.4.
} 
a polytechnic program. The school level clustered standard errors suggest that we can exclude economically significant effects. The randomization inference p-values show that all estimates are far from being statistically significant. In columns (4) to (6) we examine the situation one year after graduation. ${ }^{16}$ Again, we find no evidence on the intervention having an impact on the overall enrollment.

The second panel of Table 5 examines the impact on the log mean earnings of the field in which the accepted applicants were enrolled in. Again, the point estimates are close to zero, relatively precise and insignificant. Very similar pattern of results is repeated in columns (4) to (6) where we analyze log mean earnings of the degrees where the applicants enroll in 2013.

In panel $(\mathrm{C})$ of table 5 , we repeat the analysis with the employment rate of the degree in which the applicants were enrolled as the dependent variable. Here, the average effect in the year of graduation is actually negative and significant, but again the magnitude of this effect is negligible. The effects of our information in the year after graduation are indistinguishable from the effects of year before.

In panels $\mathrm{D}$ and $\mathrm{E}$ of Table 5, we examine whether the intervention affected applications, even if it did not affect enrollment. This analysis complements the application level analysis reported in table 4 by characterizing the application portfolios at student level. The aim is to improve statistical power and facilitate interpretation. The challenge, however, is that it is not obvious how an application portfolio should be characterized in a setting where students can apply to as many as 11 programs out of a total of 658 . This abundance of

\footnotetext{
${ }^{16}$ In columns (1) to (3), we measure enrollment for the pre-intervention cohort in fall 2011 and for the intervention cohort in 2012. In columns (4) to (6), we measure enrollment for the pre-intervention cohort in 2012 and the intervention cohort in 2013.
} 
choice also makes it infeasible to directly examine each possible combination of applications. ${ }^{17}$

Our approach is to use two ad hoc but arguably reasonable measures that characterize the application portfolio of the applicants. The first is simply the log mean earnings of the fields that the applicants include in their portfolio. While intuitive, the weakness of this measure is that it does not take into account that students may apply to programs where they are very unlikely to be admitted to. As an alternative measure, we use log expected earnings of application portfolio, where the average earnings associated with each application are weighted by the student's likelihood of being accepted (as prediceted by her matriculation exam results) and by taking into account that the student can enter only one program. ${ }^{18}$ In order to ease interpretation, we scale this outcome to have a standard deviation of one.

The results presented in panels $\mathrm{D}$ and $\mathrm{E}$ verify the conclusions from the application level analysis. The estimated impacts on the average log earnings of the application portfolio are close to zero and precisely estimated. The point estimates for the expected earnings of the application portfolio are positive, but statistically insignificant.

\footnotetext{
${ }^{17}$ There are $\left(\begin{array}{c}658 \\ 11\end{array}\right)+\left(\begin{array}{c}658 \\ 10\end{array}\right)+\ldots+\left(\begin{array}{c}658 \\ 1\end{array}\right)=2.35 \times 10^{23}$ possible application combinations. Some theoretical work examining problems approaching this level of complexity exist, but existing results are not sufficient to e.g. characterize the optimal strategy in our context. The problem is particularly hard, because preparing for an entry exam for one program decreases the likelihood of being accepted other programs (due to time constraints). Thus the tools introduced by Chade and Smith (2006) and Chade, Lewis, and Smith (in press) are not directly applicable in the Finnish context.

${ }^{18}$ See appendix B for details.
} 


\section{Interpretation}

The results discussed above suggest that our intervention led to belief updating, but had no impact on actual applications or enrollment. In this section, we discuss the potential explanations for this pattern of results. We start by showing that the students' survey answers are remarkably consistent with their later application behavior, and that the students who were disappointed about their initial choice were more likely to change their plans than the others. We then present experimental results showing that the students who were most likely to be negatively surprised were affected by the intervention. However, the affected subgroup is not sufficiently large to show up in the estimates for the full student population.

\subsection{Survey responses and application behavior}

In our survey, we asked the respondents to give us a permission to manually link their responses to the application registers. We were able to make this link for 1,168 students. For them, we can check whether they ended up applying to the program that they listed as their first choice in the survey. That is, we can examine whether their plans changed between the time of the intervention (November 2011) and the application deadline (April 2012).

Table 6 tabulates the fraction of students who applied to at least one program in the field they listed as their first choice in the survey against whether they reported to be surprised about the average earnings of recent graduates in that field. We also tabulate the fraction of students who were offered a place and the fraction accepting an offer.

The first notable fact of Table 6 is that in the spring of 2012 approximately three quarters of the students applied to the program that they had listed as 
their first choice in the survey almost half a year before the actual application process started. This suggests that the survey answers are informative about the students' intentions and that many of them had seriously considered their post-secondary education at the time of the survey. Roughly a fifth were eventually accepted to a program that they listed as their first choice in our survey.

Interestingly, however, the students who were negatively surprised were much more likely to revise their plans between the survey and the time they had to file the application. Column 4 of table 6 reports the differences between those who are negatively surprised by the actual earnings level of the field that they were thinking of and the rest of the survey respondents. These negatively surprised respondents were eight percentage points less likely to apply to the field that they reported as their first choice in the survey. The difference persists in the fraction accepted and eventually enrolling in their survey-time first choice program. There are no significant differences between the students who were positively surprised and students who were not surprised.

\subsection{Subsample analysis}

The results reported in Table 6 suggest that our intervention may have affected a subsample of students who were negatively surprised by the information we provided them. However, this hypothesis is based on a selected sample: intentions and beliefs data were only collected from the treatment group and we could link only a third of the responses to the register data. Furthermore, the association between changing plans and being negatively surprised could be spurious. In order to present plausible causal evidence, we now turn to experimental results for the subpopulation of applicants who may have been 
particularly responsive to our intervention.

Figure 5 present differences-in-differences estimates for the effect of our information intervention by different values of predicted likelihood of being negatively surprised. These predicted values are derived by estimating a linear probability model using the linked survey-register data. We regress an indicator for the respondent reporting to be negatively surprised on variables taken from the application register. ${ }^{19}$ Since we observe these variables for everyone, we can use the estimates to predict the probability of being negatively surprised for the full student population.

We split the sample into five groups along the support of the distribution of predicted surprises and conduct similar analyses as in Section 5.3 separately for each subgroup. Figure 5 shows that the resulting treatment effects are small and mostly insignificant for most values of the predicted surprises. However, among students who were the most likely to be negatively surprised, we find a significant or borderline significant positive effects on all the outcomes with randomization p-values ranging between 0.144 and 0.000 (Appendix Table C.6). That is, individuals who are the most likely to update their beliefs appear to change their application behavior and their enrollment is affected by the intervention. They switch their applications towards programs with higher wages and are more likely to be enrolled in a program that pays higher wages. However, this group is only a small fraction of the overall student population and thus it does not affect our estimates regarding the average effect of the intervention. ${ }^{20}$

\footnotetext{
${ }^{19}$ The regressors are female dummy, full set of dummies for the optional subjects taken in the matriculation exam and the average matriculation grade in the school in 2011. We present the results of the regressions in Appendix Table C.5.

${ }^{20}$ In the Appendix, we show that similar conclusions follow from estimates where we split the sample into equally sized subgroups (Appendix Table C.7) as well as from a specification adding a linear interaction term between the predicted surprise and treatment group status
} 


\section{Conclusions}

Many commentators, politicians, and parents worry that high-school students choose post-secondary education that does not prepare them for a successful entry into the labor market. Often these choices are alleged to reflect a lack of information about actual labor market prospects associated with alternative degrees. Yet, the mere fact that some choices do not appear to maximize lifetime earnings does not necessarily mean that they are based on incomplete information. Degrees that offer poor labor market prospects may attract students with their consumption value. On the other hand, degrees that are associated with high earnings and employment rates are often heavily over-subscribed.

In this paper, we have reported results from a large randomized field experiment that provided accurate and detailed information about the earnings distribution and employment prospects associated with different post-secondary degrees in Finland. Our survey results confirm the findings from previous literature that these kinds of information interventions lead to belief updating. However, our experimental estimates show that the intervention did not affect the actual application or enrollment patterns, on average. Only those students who were the most likely to be negatively surprised switched to apply to programs that have higher average earnings. They also became more likely enroll into such programs. While the effects are statistically and economically significant for this subgroup, the subgroup represents a small fraction of the overall student population.

Our results suggest two policy lessons. First, providing accurate information on the labor market prospects is likely to be welfare increasing. Given the (Appendix Table C.8). 
importance of post-secondary education choices - and the low cost of providing information - affecting even a small fraction of students provides a justification for this type of interventions. Second, it is important to bear in mind that better information alone is unlikely to have a major impact on the overall allocation of students into post-secondary programs. Thus governments worried about students making "wrong" decisions are best adviced to seek additional policy measures. 


\section{References}

Altonji, J. G., Blom, E., \& Meghir, C. (2012). Heterogeneity in human capital investments: High school curriculum, college major, and careers. Annual Review of Economics, 4 (1), 185-223.

Bettinger, E. P., Long, B. T., Oreopoulos, P., \& Sanbonmatsu, L. (2012). The Role of Application Assistance and Information in College Decisions: Results from the H\&R Block Fafsa Experiment. The Quarterly Journal of Economics, 127(3), 1205-1242.

Betts, J. R. (1996). What do students know about wages? evidence from a survey of undergraduates. Journal of Human Resources, 27-56.

Brunello, G., Lucifora, C., \& Winter-Ebmer, R. (2004). The wage expectations of european business and economics students. Journal of Human Resources, 39(4), 1116-1142.

Carvajal, M. J., Bendana, D., Bozorgmanesh, A., Castillo, M. A., Pourmasiha, K., Rao, P., \& Torres, J. A. (2000). Inter-gender differentials between college students' earnings expectations and the experience of recent graduates. Economics of Education Review, 19(3), 229-243.

Chade, H., Lewis, G., \& Smith, L. (in press). Student portfolios and the college admissions problem. Review of Economic Studies.

Chade, H., \& Smith, L. (2006). Simultaneous search. Econometrica, 74(5), 1293-1307.

Dominitz, J., \& Manski, C. F. (1996). Eliciting student expectations of the returns to schooling. Journal of Human Resources, 31(1), 1-26.

Fisher, R. A. (1935). The design of experiments. Oliver \& Boyd.

Hastings, J., Neilson, C. A., \& Zimmerman, S. D. (2015). The effects of earnings disclosure on college enrollment decisions (Tech. Rep.). National 
Bureau of Economic Research.

Hoxby, C., \& Avery, C. (2013). The Missing "One-Offs": The Hidden Supply of High-Achieving, Low Income Students. Brookings Papers on Economic Activity, 1, 1-65.

Hoxby, C., \& Turner, S. (2013). Expanding college opportunities for highachieving, low income students. (Mimeo)

Jensen, R. (2010). The (Perceived) Returns to Education and the Demand for Schooling. The Quarterly Journal of Economics, 125(2), 515-548.

Kirkebøen, L., Leuven, E., \& Mogstad, M. (2014). Field of study, earnings, and self-selection. (NBER WP No. 20816)

McGuigan, M., McNally, S., \& Wyness, G. (2012). Student awareness of costs and benefits of educational decisions: Effects of an information campaign. (CEE DP 139)

Nguyen, T. (2008). Information, Role Models and Perceived Returns to Education: Experimental Evidence from Madagascar. (Mimeo)

Oreopoulos, P., \& Dunn, R. (2013). Information and college access: Evidence from a randomized field experiment. The Scandinavian Journal of Economics, 115(1), 3-26.

Rosenbaum, P. R. (2002). Covariance adjustment in randomized experiments and observational studies. Statistical Science, 17(3), 286-327.

Wiswall, M., \& Zafar, B. (in press). Determinants of college major choice: Identification using an information experiment. Review of Economic Studies. 
Figure 1: The timing of the treatment within the Finnish educational system

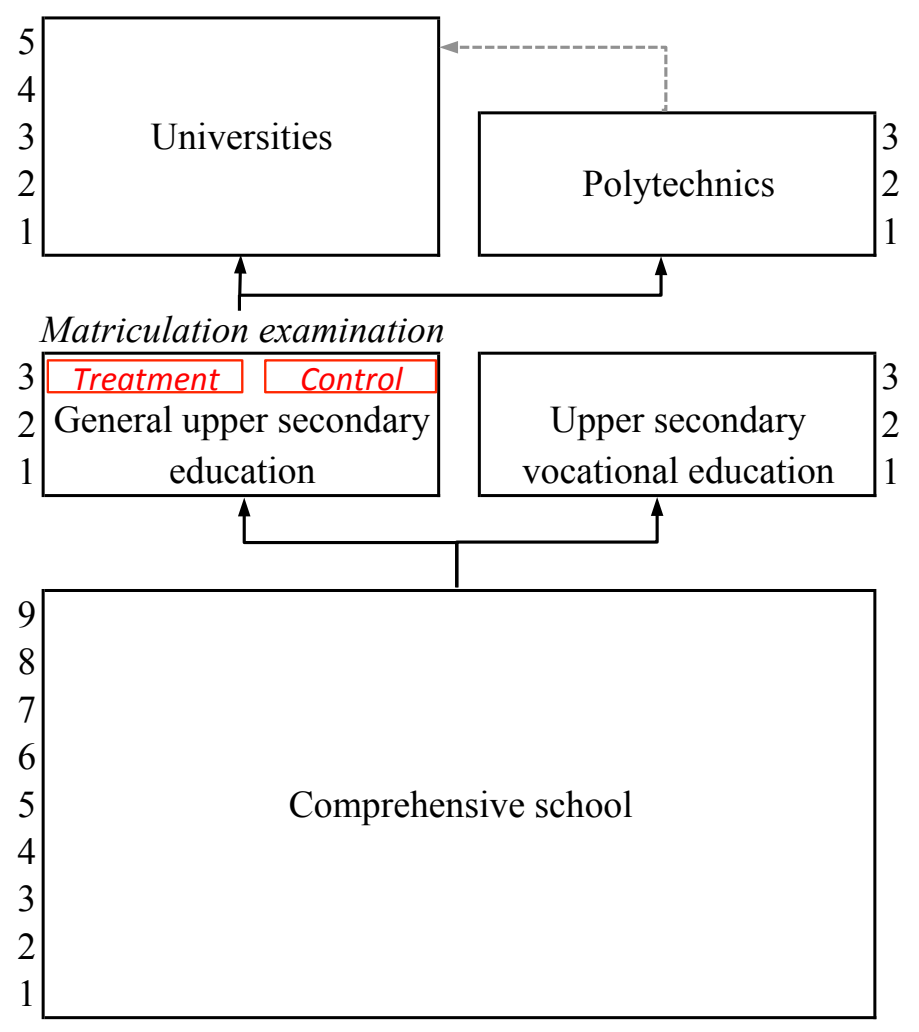


Figure 2: Average earnings and matriculation exam scores among enrolled students

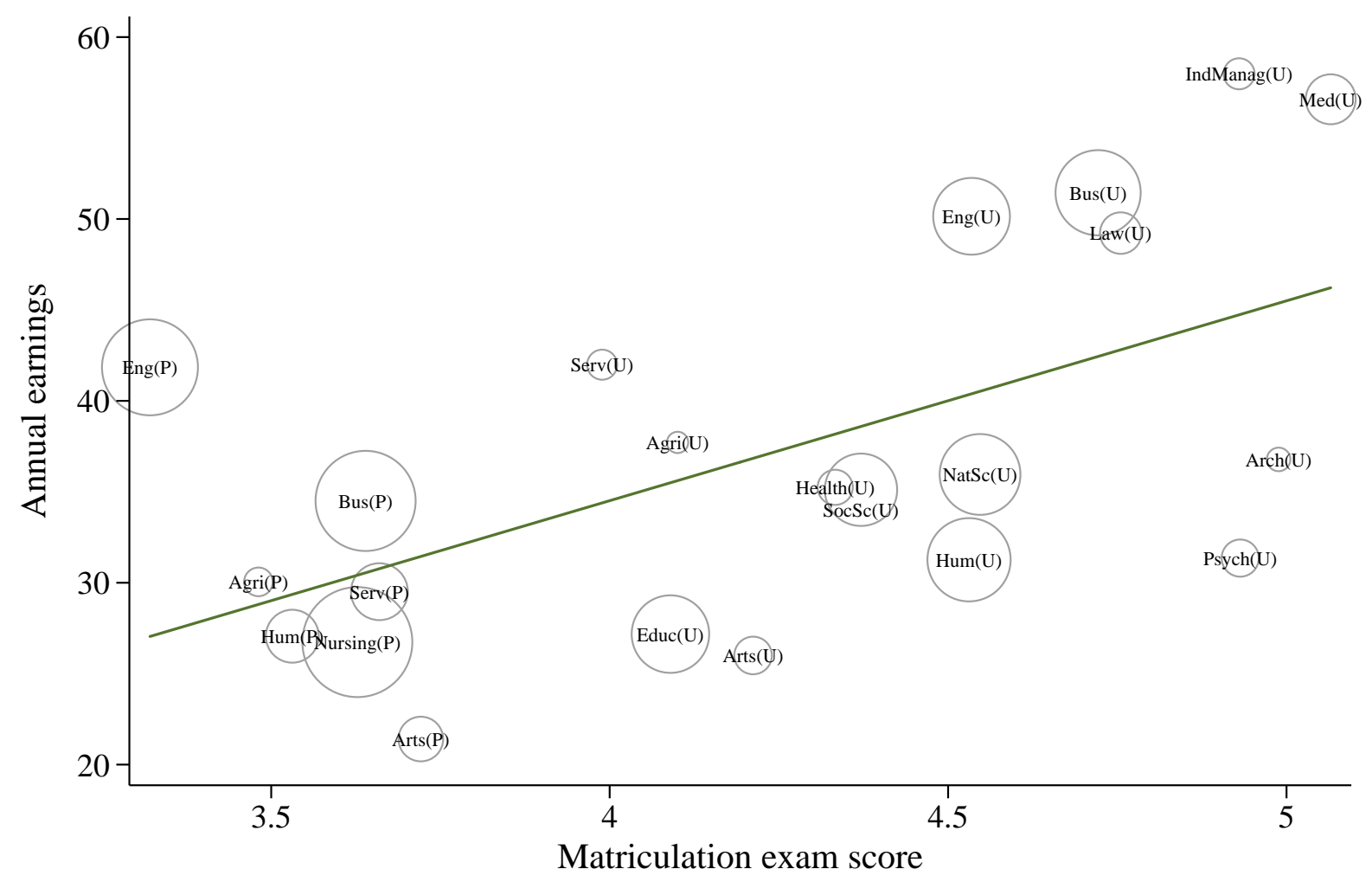

Note: Average earnings of the 30-34 old individuals in 2008 holding a degree (vertical axis) and the average matriculation exam scores of the students enrolled in these programs in 2011-2013 (horizontal axis). The size of the circles corresponds to the number of students enrolled in the program in 2011-2013. 
Figure 3: Extract from the slides provided to the student guidance councelors

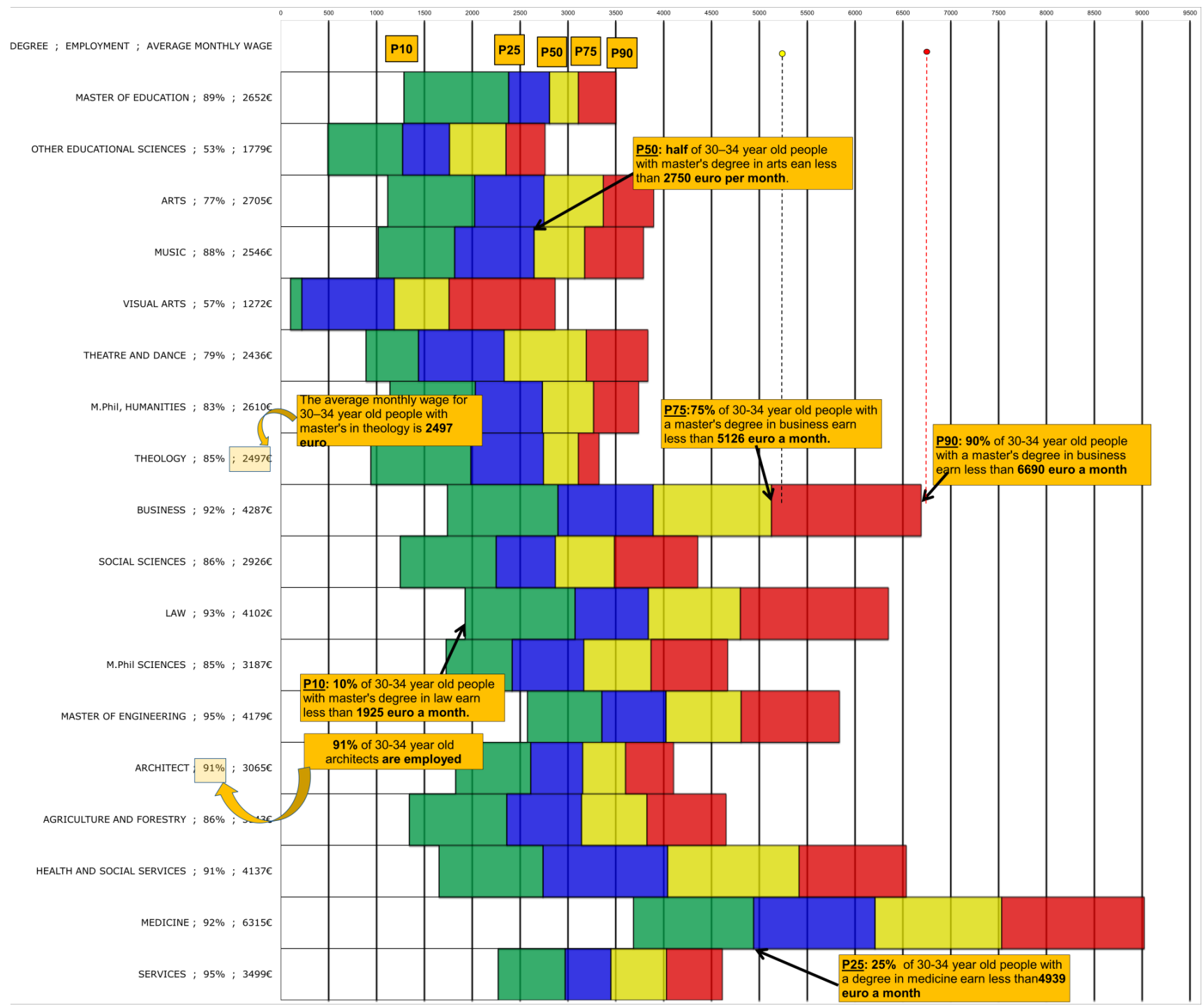

Note: Slide 8 form the PowerPoint presentation provided to the student guidance councelors. Similar distributional graphs were provided in the information package regarding 104 degrees. We instructed the student guidance councelors to go through this slide slowly and provided detailed discussion about how to interpret it. See the treatment material, pages 3-4, for details (available at www.aalto-econ.fi/sarvimaki). 

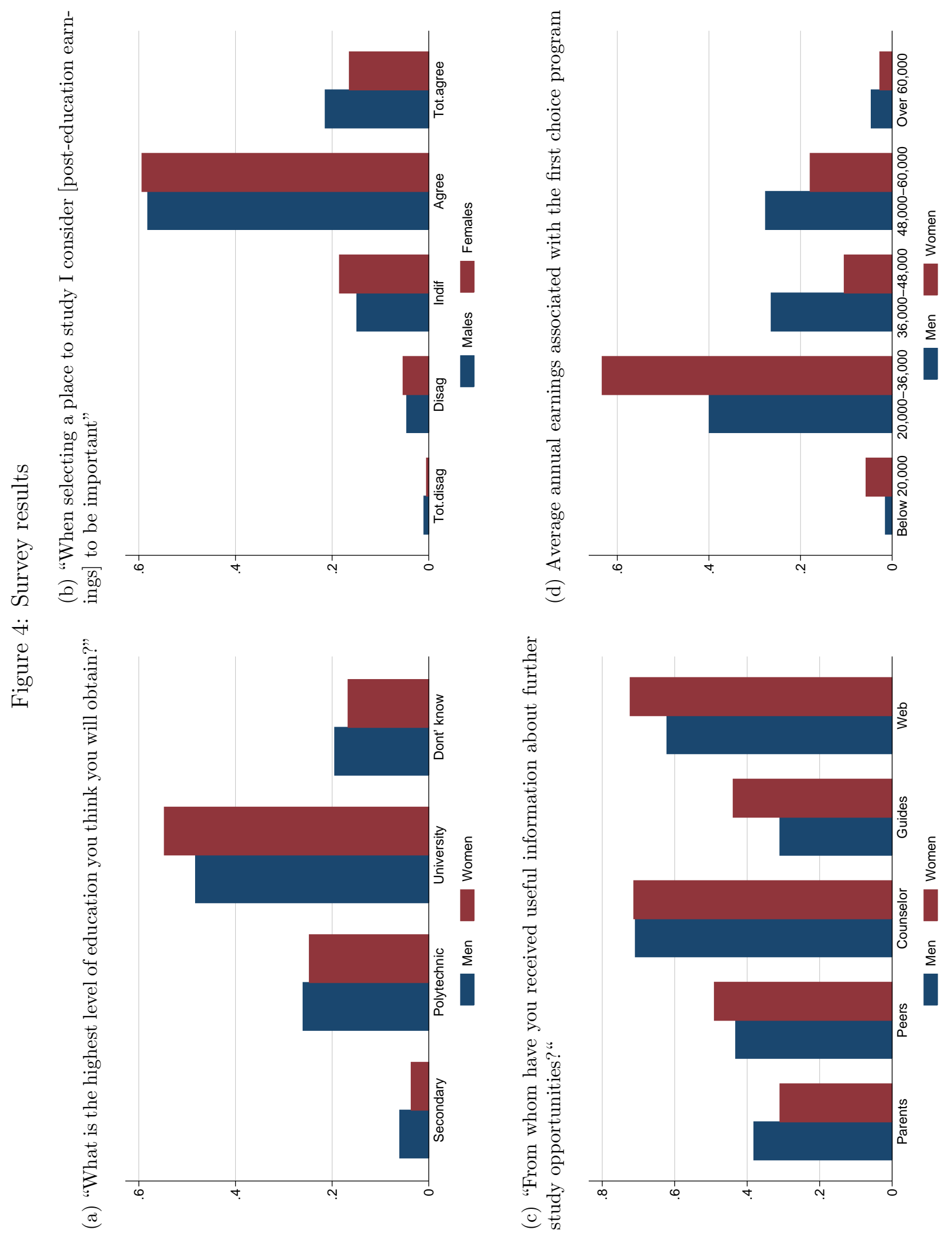


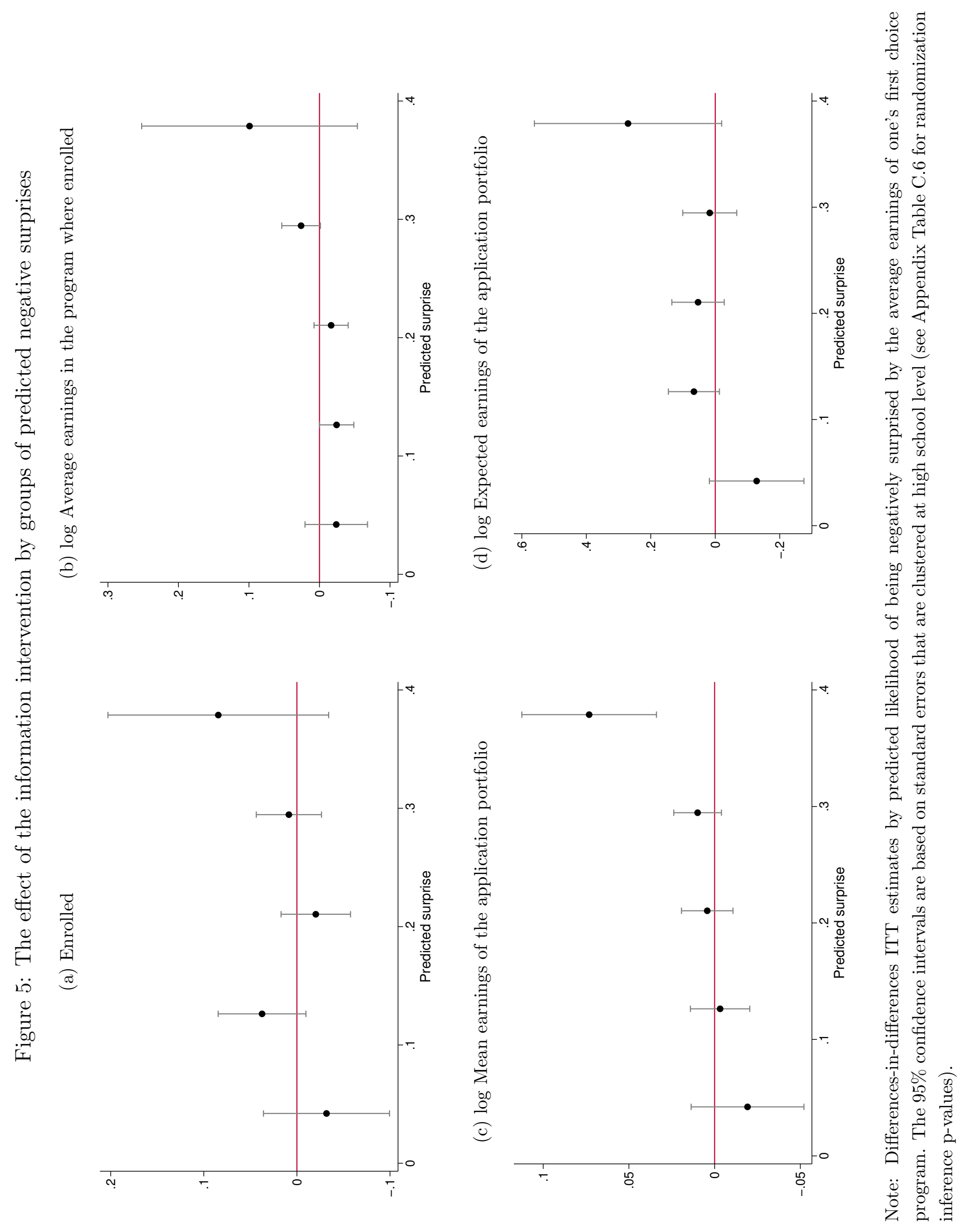




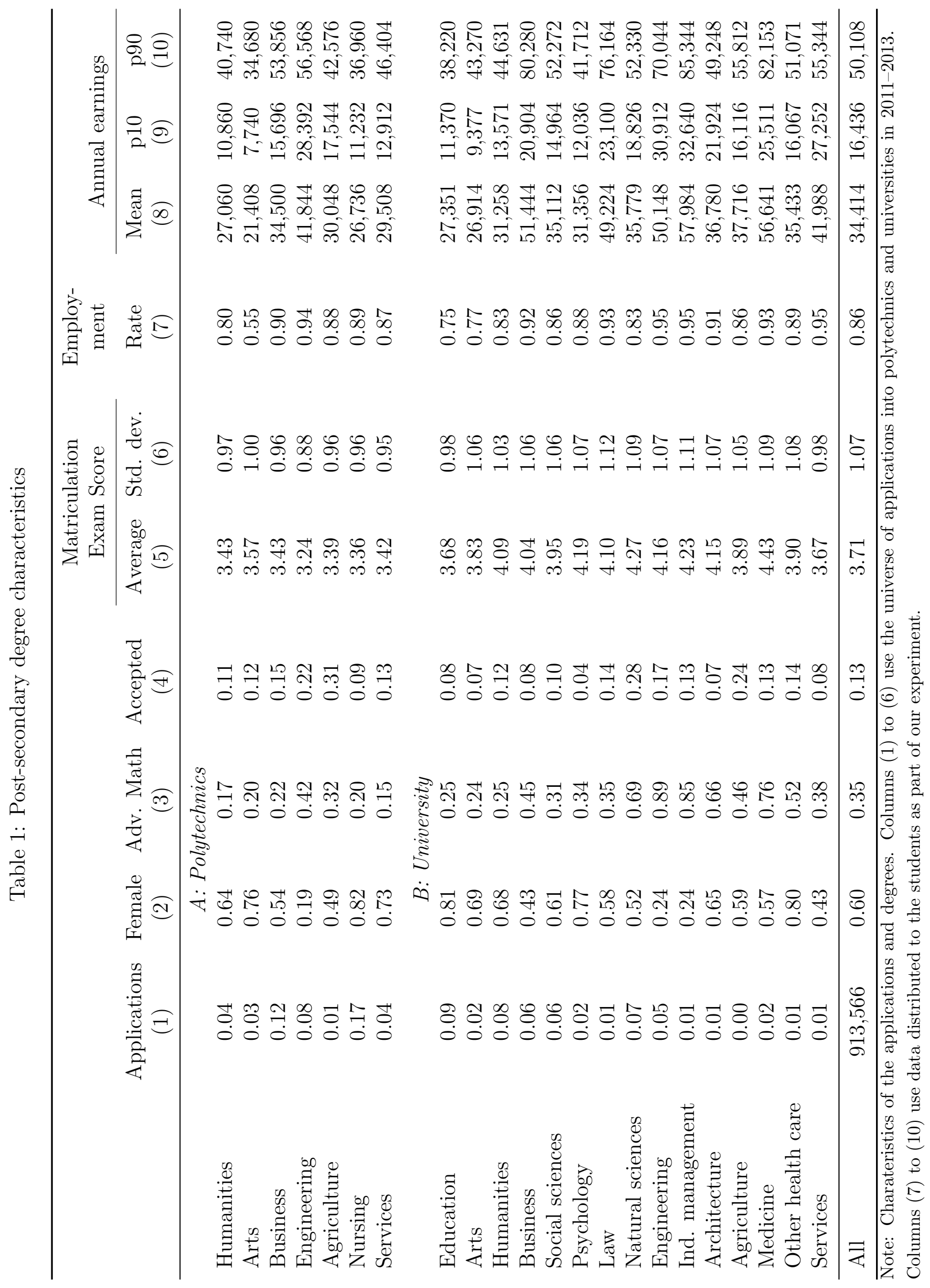


Table 2: Belief updating by background characteristics and survey responses

\begin{tabular}{|c|c|c|c|}
\hline & $\begin{array}{l}\text { Earnings } \\
\text { less than } \\
\text { expected }\end{array}$ & $\begin{array}{c}\text { Earnings } \\
\text { equal to } \\
\text { expectations }\end{array}$ & $\begin{array}{l}\text { Earnings } \\
\text { larger than } \\
\text { expected }\end{array}$ \\
\hline \multicolumn{4}{|l|}{ A: Gender } \\
\hline Men & 14.4 & 64.0 & 21.6 \\
\hline Women & 23.4 & 60.1 & 15.8 \\
\hline \multicolumn{4}{|c|}{ B: "I think I know enough about the effect of education choices on earnings" } \\
\hline No & 28.5 & 53.8 & 17.7 \\
\hline Yes & 15.4 & 66.3 & 18.3 \\
\hline \multicolumn{4}{|c|}{ C: "When selecting a place to study I consider post-education earnings to be important" } \\
\hline Disagree & 16.8 & 62.0 & 21.2 \\
\hline Agree & 20.8 & 62.1 & 17.1 \\
\hline \multicolumn{4}{|c|}{ D: Takes advanced math in the matriculation exam } \\
\hline No & 23.4 & 60.7 & 16.0 \\
\hline Yes & 15.0 & 64.1 & 20.9 \\
\hline \multicolumn{4}{|c|}{ E: Own matriculation exam score } \\
\hline Below median & 20.6 & 61.3 & 18.2 \\
\hline Above median & 19.3 & 62.8 & 18.0 \\
\hline \multicolumn{4}{|c|}{ F: School's average matriculation exam score } \\
\hline Below median & 23.2 & 60.9 & 15.8 \\
\hline Above median & 18.4 & 62.6 & 19.0 \\
\hline All & 19.9 & 62.1 & 18.1 \\
\hline
\end{tabular}


Table 3: Updating Beliefs about Average Wages by Field

\begin{tabular}{|c|c|c|c|c|c|c|}
\hline & $\begin{array}{l}\text { Earnings } \\
\text { less than } \\
\text { expected }\end{array}$ & $\begin{array}{l}\text { Earnings } \\
\text { equal to } \\
\text { expectations }\end{array}$ & $\begin{array}{l}\text { Earnings } \\
\text { larger than } \\
\text { expected }\end{array}$ & $\begin{array}{c}\text { Did } \\
\text { not } \\
\text { answer }\end{array}$ & Mean & Obs. \\
\hline \multicolumn{7}{|c|}{ A: Polytechnics } \\
\hline Humanities & 0.18 & 0.55 & 0.15 & 0.11 & -0.03 & 123 \\
\hline Arts & 0.25 & 0.25 & 0.13 & 0.38 & -0.20 & 8 \\
\hline Business & 0.16 & 0.68 & 0.12 & 0.04 & -0.05 & 135 \\
\hline Engineering & 0.09 & 0.64 & 0.21 & 0.05 & 0.13 & 118 \\
\hline Agriculture & 0.26 & 0.57 & 0.13 & 0.04 & -0.14 & 23 \\
\hline Nursing & 0.19 & 0.69 & 0.08 & 0.05 & -0.12 & 278 \\
\hline Services & 0.24 & 0.62 & 0.05 & 0.10 & -0.21 & 156 \\
\hline \multicolumn{7}{|c|}{ B: Universities } \\
\hline Education & 0.37 & 0.55 & 0.05 & 0.02 & -0.33 & 167 \\
\hline Arts & 0.21 & 0.49 & 0.23 & 0.07 & 0.02 & 61 \\
\hline Humanities & 0.19 & 0.64 & 0.13 & 0.04 & -0.06 & 189 \\
\hline Business & 0.04 & 0.62 & 0.31 & 0.03 & 0.28 & 271 \\
\hline Social sciences & 0.25 & 0.61 & 0.08 & 0.07 & -0.19 & 104 \\
\hline Psychology & 0.57 & 0.35 & 0.05 & 0.04 & -0.54 & 109 \\
\hline Law & 0.08 & 0.78 & 0.13 & 0.01 & 0.04 & 159 \\
\hline Natural sciences & 0.24 & 0.56 & 0.11 & 0.09 & -0.14 & 117 \\
\hline Engineering & 0.08 & 0.62 & 0.27 & 0.03 & 0.20 & 128 \\
\hline Ind. management & 0.00 & 0.50 & 0.40 & 0.10 & 0.44 & 10 \\
\hline Architecture & 0.26 & 0.55 & 0.11 & 0.08 & -0.17 & 38 \\
\hline Agriculture & 0.00 & 0.56 & 0.44 & 0.00 & 0.44 & 9 \\
\hline Medicine & 0.04 & 0.68 & 0.25 & 0.02 & 0.22 & 221 \\
\hline Other health care & 0.34 & 0.52 & 0.09 & 0.05 & -0.27 & 93 \\
\hline Services & 0.25 & 0.60 & 0.11 & 0.04 & -0.14 & 81 \\
\hline Total & 0.19 & 0.62 & 0.15 & 0.05 & 2,5 & \\
\hline
\end{tabular}

Note: The average updating is calculated by assigning value -1 for negative, 1 for positive, and 0 for no surprises. The measurement of surprises by field is based on students who listed a program in that field as their number one choice at the time of survey. 
Table 4: Applications by Field, Year and Treatment Group

\begin{tabular}{|c|c|c|c|c|c|c|}
\hline & \multicolumn{2}{|c|}{2011} & \multicolumn{2}{|c|}{2012} & \multicolumn{2}{|c|}{2012 vs. 2011} \\
\hline & $\begin{array}{c}\text { Control } \\
\text { (1) }\end{array}$ & $\begin{array}{c}\text { Treated } \\
(2)\end{array}$ & $\begin{array}{c}\text { Control } \\
\text { (3) }\end{array}$ & $\begin{array}{c}\text { Treated } \\
(4)\end{array}$ & $\begin{array}{l}\text { OR } \\
(5)\end{array}$ & $\begin{array}{c}\text { p-value } \\
(6)\end{array}$ \\
\hline \multicolumn{7}{|c|}{ A: Polytechnics } \\
\hline Humanities & 0.03 & 0.03 & 0.03 & 0.03 & 0.99 & 0.954 \\
\hline Arts & 0.03 & 0.03 & 0.03 & 0.02 & 0.91 & 0.328 \\
\hline Business & 0.10 & 0.10 & 0.10 & 0.11 & 1.10 & 0.191 \\
\hline Engineering & 0.07 & 0.08 & 0.07 & 0.07 & 0.94 & 0.490 \\
\hline Agriculture & 0.01 & 0.01 & 0.01 & 0.01 & 1.06 & 0.677 \\
\hline Nursing & 0.15 & 0.15 & 0.15 & 0.15 & 1.06 & 0.267 \\
\hline Services & 0.05 & 0.04 & 0.04 & 0.04 & 1.09 & 0.362 \\
\hline \multicolumn{7}{|c|}{ B: Universities } \\
\hline Education & 0.07 & 0.07 & 0.08 & 0.07 & 0.95 & 0.587 \\
\hline Arts & 0.02 & 0.01 & 0.01 & 0.01 & 1.11 & 0.390 \\
\hline Humanities & 0.09 & 0.09 & 0.09 & 0.09 & 1.06 & 0.410 \\
\hline Business & 0.06 & 0.05 & 0.06 & 0.06 & 1.06 & 0.450 \\
\hline Social sciences & 0.05 & 0.06 & 0.05 & 0.05 & 1.00 & 0.971 \\
\hline Psychology & 0.02 & 0.02 & 0.02 & 0.02 & 0.94 & 0.605 \\
\hline Law & 0.01 & 0.01 & 0.01 & 0.01 & 0.94 & 0.550 \\
\hline Natural sciences & 0.10 & 0.11 & 0.10 & 0.10 & 0.97 & 0.615 \\
\hline Engineering & 0.08 & 0.08 & 0.08 & 0.08 & 0.97 & 0.667 \\
\hline Ind. management & 0.01 & 0.01 & 0.01 & 0.01 & 0.92 & 0.569 \\
\hline Architecture & 0.01 & 0.00 & 0.01 & 0.01 & 1.50 & 0.033 \\
\hline Agriculture & 0.00 & 0.00 & 0.00 & 0.00 & 1.03 & 0.888 \\
\hline Medicine & 0.01 & 0.01 & 0.02 & 0.02 & 1.01 & 0.927 \\
\hline Other health care & 0.01 & 0.01 & 0.01 & 0.01 & 0.86 & 0.266 \\
\hline Services & 0.01 & 0.01 & 0.01 & 0.01 & 0.88 & 0.462 \\
\hline Applications & 72,128 & 23,728 & 71,156 & 23,720 & \multicolumn{2}{|c|}{190,732} \\
\hline \multicolumn{7}{|c|}{$\begin{array}{l}\text { Note: Columns } 1 \text { to } 4 \text { report the distribution of applications from the treatment and control high- } \\
\text { schools in } 2011 \text { (pre-treatment) and } 2012 \text { (post-treatment) among graduating students. Column } \\
5 \text { reports odds ratios for the change between years } 2011 \text { and } 2012 \text { by treatment status. Column } \\
6 \text { reports p-values for the odds ratios using randomization inference (see the text for discussion). } \\
\text { The randomization inference p-value for testing homogeneity of odds-ratios is } 0.782 \text {. }\end{array}$} \\
\hline
\end{tabular}


Table 5: The effect of the information intervention

\begin{tabular}{|c|c|c|c|c|c|c|c|}
\hline & \multirow[b]{2}{*}{ Dependent variable } & \multicolumn{3}{|c|}{ Year of graduation } & \multicolumn{3}{|c|}{ Year after graduation } \\
\hline & & $\begin{array}{l}\text { All } \\
\text { (1) }\end{array}$ & $\begin{array}{c}\text { Men } \\
(2)\end{array}$ & $\begin{array}{c}\text { Women } \\
(3)\end{array}$ & $\begin{array}{l}\text { All } \\
(4)\end{array}$ & $\begin{array}{c}\text { Men } \\
(5)\end{array}$ & $\begin{array}{c}\text { Women } \\
\quad(6)\end{array}$ \\
\hline (A) & Enrolled & $\begin{array}{l}-0.001 \\
(0.011) \\
{[0.919]}\end{array}$ & $\begin{array}{l}-0.014 \\
(0.020) \\
{[0.430]}\end{array}$ & $\begin{array}{l}0.010 \\
(0.013) \\
{[0.488]}\end{array}$ & $\begin{array}{c}0.010 \\
(0.017) \\
{[0.369]}\end{array}$ & $\begin{array}{c}0.008 \\
(0.022) \\
{[0.631]}\end{array}$ & $\begin{array}{c}0.012 \\
(0.022) \\
{[0.407]}\end{array}$ \\
\hline (B) & $\begin{array}{l}\text { log Average earnings } \\
\text { in the program } \\
\text { where enrolled }\end{array}$ & $\begin{array}{l}-0.012 \\
(0.007) \\
{[0.157]}\end{array}$ & $\begin{array}{l}-0.008 \\
(0.008) \\
{[0.289]}\end{array}$ & $\begin{array}{l}-0.005 \\
(0.010) \\
{[0.606]}\end{array}$ & $\begin{array}{l}-0.002 \\
(0.011) \\
{[0.804]}\end{array}$ & $\begin{array}{l}-0.011 \\
(0.014) \\
{[0.321]}\end{array}$ & $\begin{array}{c}0.009 \\
(0.013) \\
{[0.366]}\end{array}$ \\
\hline (C) & $\begin{array}{l}\text { Average employment } \\
\text { rate in the program } \\
\text { where enrolled }\end{array}$ & $\begin{array}{l}-0.003 \\
(0.002) \\
{[0.049]}\end{array}$ & $\begin{array}{l}-0.002 \\
(0.002) \\
{[0.138]}\end{array}$ & $\begin{array}{l}-0.003 \\
(0.002) \\
{[0.173]}\end{array}$ & $\begin{array}{l}-0.003 \\
(0.002) \\
{[0.203]}\end{array}$ & $\begin{array}{l}-0.001 \\
(0.003) \\
{[0.601]}\end{array}$ & $\begin{array}{l}-0.002 \\
(0.003) \\
{[0.357]}\end{array}$ \\
\hline (D) & $\begin{array}{l}\text { log Mean earnings } \\
\text { of the application } \\
\text { portfolio }\end{array}$ & $\begin{array}{l}-0.002 \\
(0.006) \\
{[0.815]}\end{array}$ & $\begin{array}{l}-0.005 \\
(0.008) \\
{[0.491]}\end{array}$ & $\begin{array}{c}0.005 \\
(0.006) \\
{[0.535]}\end{array}$ & $\begin{array}{c}0.004 \\
(0.006) \\
{[0.644]}\end{array}$ & $\begin{array}{c}0.003 \\
(0.009) \\
{[0.734]}\end{array}$ & $\begin{array}{c}0.009 \\
(0.007) \\
{[0.289]}\end{array}$ \\
\hline (E) & $\begin{array}{l}\text { log Expected earnings } \\
\text { of the application } \\
\text { portfolio }\end{array}$ & $\begin{array}{c}0.019 \\
(0.024) \\
{[0.511]}\end{array}$ & $\begin{array}{c}0.057 \\
(0.038) \\
{[0.120]}\end{array}$ & $\begin{array}{c}0.000 \\
(0.031) \\
{[0.992]}\end{array}$ & $\begin{array}{l}-0.004 \\
(0.028) \\
{[0.906]}\end{array}$ & $\begin{array}{c}0.010 \\
(0.045) \\
{[0.801]}\end{array}$ & $\begin{array}{l}-0.002 \\
(0.034) \\
{[0.959]}\end{array}$ \\
\hline
\end{tabular}

Note: Differences-in-differences ITT estimates, school-level clustered standard errors (in parantheses) and randomization inference p-values [in brackets] using 10,000 replications. Log expected value of the application portfolio is scaled to have a standard deviation of one. 
Table 6: Belief updating and application behavior

\begin{tabular}{|c|c|c|c|c|c|}
\hline & $\begin{array}{l}\text { Earnings } \\
\text { less than } \\
\text { expected }\end{array}$ & $\begin{array}{c}\text { Earnings } \\
\text { equal to } \\
\text { expectations }\end{array}$ & $\begin{array}{l}\text { Earnings } \\
\text { larger than } \\
\text { expected }\end{array}$ & Total & $\begin{array}{l}\chi^{2} \text {-test } \\
\text { p-value }\end{array}$ \\
\hline $\begin{array}{l}\text { Applied to first } \\
\text { choice program }\end{array}$ & 67.2 & 75.5 & 75.8 & 73.9 & 0.036 \\
\hline $\begin{array}{l}\text { Accepted to first } \\
\text { choice program }\end{array}$ & 16.8 & 22.2 & 24.6 & 21.6 & 0.108 \\
\hline $\begin{array}{l}\text { Enrolled in first } \\
\text { choice program }\end{array}$ & 14.2 & 20.8 & 23.2 & 20.0 & 0.038 \\
\hline $\mathrm{N}$ & 232 & 725 & 211 & 1,168 & \\
\hline \multicolumn{6}{|c|}{$\begin{array}{l}\text { Note: Fractions of students whose survey responses could be matched to register data and whe } \\
\text { applied to a program that they listed as their most likely choice (first row), were admitted to } \\
\text { their first choice program (second row) and eventually enrolled in their first choice progran } \\
\text { in the fall term of High School graduation year (third row). The numbers are calculatec } \\
\text { separately for students who responded that average earnings in their first choice program ir } \\
\text { the data they were provided along with the survey were more than, equal to or less than they } \\
\text { had expected. Differences across these groups are tested using a simple } \chi^{2} \text {-test. }\end{array}$} \\
\hline
\end{tabular}




\section{A Details of the experiment}

\section{A.1 Target schools}

We started designing the experiment by collecting a list of all 431 Finnish high schools. We dropped evening and adult high schools, and other speciality schools such as religious institutes, resulting in a reduction of 32 schools. We further excluded the only high school in the autonomous Aland archipelago and another school operating in Spain for Finnish students located there, as well as any Swedish language high schools, or schools specializing in another language (e.g. French, German or Russian). Our final target group is the 2011 list of operating Finnish language schools which includes 363 high schools in the continental Finland.

\section{A.2 Randomization}

We used a randomized block design where we split the schools into bins of four school based on the province they are located in and their average matriculation examination grades during 2007-2010. When the number of schools was not divisible by four, the location of the incomplete bin in the ranking distribution was randomly selected. We then randomly selected one from each bin. Figure A.1 illustrates the research design by plotting schools againts the average grades within six provinces (out of the total 18 provinces). It shows how our treatment group consists of schools from the top and bottom of the ranking, in some cases including the very best or worst school in the province. The final treatment group consisted of 97 high schools.

\section{A.3 Balancing tests}

Table A.1 examines the average characteristics of the treatment and control schools in 2011. There are no significant differences in the average matriculation grades of the treatment and control schools. The table also reports information on the background characteristics of the students using Statistics Finland's geocode data that reports the average share of high school and university graduates and the average household income by $250 \mathrm{~m}$ x $250 \mathrm{~m}$ squares $(0.05$ square miles or 30 acres). These data were linked to the application register using students' addresses. None of these background variables differ significantly between the treatment and control schools, with the borderline exception of regional unemployment. These results suggest that the randomization worked as intended.

\section{A.4 Student guidance counselors}

The student guidance counselors in high schools have multiple roles within the institution. According to a recent survey of 213 guidance counselors, their core tasks involve counseling, information sharing, planning, and "networking with stakeholders". ${ }^{21}$ Each student works individually with the counselor to create their study plan which includes course choices,

\footnotetext{
${ }^{21}$ Source: Lukion opinto-ohjaajan työnkuva- ja palkkauskysely 2011 ("High school guidance counselor job and salary survey 2011").
} 
plans for the matriculation exam and plans for further education. In addition, the guidance counselors are responsible for student welfare, marketing, recruiting, development of the student counseling, and institution specific tasks assigned by the headmaster. The latter consist of monitoring exams, creating study guides, guiding visitors, a variety of control tasks, and receiving the matriculation examination registration forms. Most also maintain a website that includes links to universities and polytechnics, a link to the centralized tertiary education application system, and any other links that the counselor views relevant.

The job of student guidance counselors has evolved rapidly in recent years. Some of these changes are related to the matriculation examination reforms, changes in the organization and selection criteria in the polytechnics and universities, and the increased choices around the timing and content of the matriculation exam that has especially increased the work load

with students at risk of dropping out and/or immigrant students. According to the guidance counselors, adjusting to these changes is taking up an increasing amount of their time and allowing them to spend less time on "traditional counseling activities".

\section{A.5 Pilot study}

Before implementing the intervention in the treatment schools we piloted the entire experiment in a single high school during spring 2011. Most students (89\%) in the pilot school thought the information on the labor market prospects related to education should be made available in all schools. Likewise, students in our treatment schools indicated that the information was novel and useful, and the guidance councellors appeared enthusiastic about the materials. Based on the responses from the participating schools and the overall tone in the open-ended comments from students we expect the intervention to have been successful in communicating the message on the labor market prospects to participating students. The pilot school is excluded from our sample. 
Figure A.1: Illustration of the randomized block design
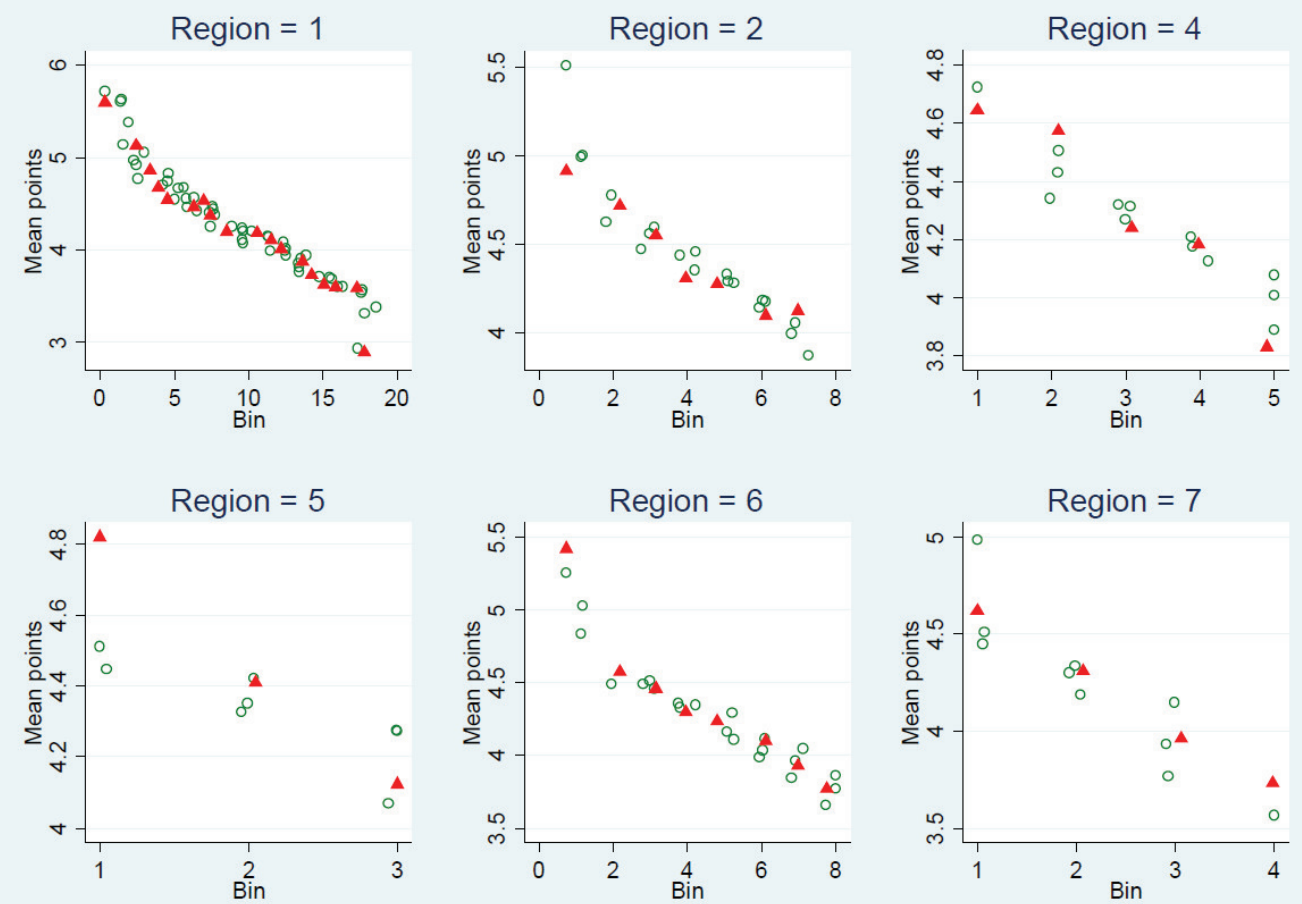

Note: Distribution of high-schools in 6 example provinces. Schools are ranked according to the average matriculation grade of students graduating in 2007-2010, and divided into bins of four. Schools within the same bin are clustered together in the plot, and treatment schools are indicated with a triangle. 
Table A.1: Average background variables in treatment and control schools

\begin{tabular}{|c|c|c|c|c|c|c|c|}
\hline & \multicolumn{2}{|c|}{$\begin{array}{l}\text { Treatment } \\
\text { schools }\end{array}$} & \multicolumn{2}{|c|}{$\begin{array}{l}\text { Control } \\
\text { schools }\end{array}$} & \multicolumn{3}{|c|}{ Difference } \\
\hline & Mean & $\mathrm{sd}$. & Mean & $\mathrm{sd}$. & Diff. & se. & p-value \\
\hline $\begin{array}{l}\text { Average matriculation } \\
\text { grade } 2011\end{array}$ & 3.769 & 0.359 & 3.799 & 0.392 & -0.030 & 0.044 & 0.496 \\
\hline $\begin{array}{l}\text { Share holding Bachelor/Masters } \\
\text { degree in the neighborhood }\end{array}$ & 0.191 & 0.099 & 0.195 & 0.086 & -0.004 & 0.011 & 0.708 \\
\hline $\begin{array}{l}\text { Share holding Masters } \\
\text { degree in the neighborhood }\end{array}$ & 0.103 & 0.081 & 0.104 & 0.069 & -0.001 & 0.009 & 0.906 \\
\hline $\begin{array}{l}\text { Average household income } \\
\text { in the neighborhood }\end{array}$ & 30,314 & 18,653 & 32,469 & 17,266 & $-2,155$ & 2,171 & 0.322 \\
\hline Regional unemployment rate & 0.098 & 0.044 & 0.089 & 0.043 & 0.010 & 0.005 & 0.065 \\
\hline Number of high schools & \multicolumn{2}{|c|}{97} & \multicolumn{2}{|c|}{266} & & & \\
\hline
\end{tabular}




\section{B Constructing expected earnings of an application portfolio}

We measure the expected income associated with an application portfolio of each individual as

$$
V_{i}=p_{i 1} E_{1}+\sum_{j=2}^{J_{i}}\left[\prod_{n=1}^{j-1}\left(1-p_{i n}\right)\right] p_{i j} E_{j}
$$

where $p_{i j}$ is the probability that person $i$ is admitted to her $j^{\text {th }}$ choice, and $E_{j}$ is the expected earnings associated with her $j^{\text {th }}$ choice. The logic of this measure is the following. If a person applies to only one program, she can either be admitted and receive $E_{1}$ or be rejected and get her outside option (normalized as zero). The probability that she is admitted is $p_{i 1}$ and thus her expected income is $p_{i 1} E_{1}$. If instead she applies to two programs, she can be admitted to her first choice and receive $E_{1}$, be rejected from the first choice but admitted to the second and get $E_{2}$, or be rejected from both and get nothing. Thus her expected income is $p_{i 1} E_{1}+\left(1-p_{i 1}\right) p_{i 2} E_{2}$. Equation (B1) generalizes this idea for a person applying to $J_{i}$ programs.

A useful feature of this measure is that the $p_{i}$ is person specific and thus applying to a high paying program increases expected income only to the extent that the person has a chance of being admitted. We estimate these probabilities using the 2011 application register data. For each program, we take all applicants and regress an indicator for being accepted on the matriculation exam results of the applicants using a flexible specification (dummies for each possible grade in the four subjects of the matriculation exam and interacting math grades with a dummy for long curriculum). Using estimates from these regressions, we then construct the probabilities that an application in our data would be admitted.

The approach also has three important limitations. First, it could be sensitive to the ranking of applications. We do not observe these rankings in our data and thus we have to impose them. For our baseline results, we have assumed that the students rank their applications based on the average earnings of each degree (in the order from the largest to the smallest). In order to examine the importance of this assumption, we have also experimented with a random ranking and a ranking based on the likelihood of being accepted to a program. We reach similar conclusions with all these approaches and thus conclude that the issue is not important in practice. Second, the approximation of the expected income is based on degree-level averages and therefore does not take into account any within-degree heterogeneity. Third, the calculation of the expected income of the portfolio is based on the assumption that the elements of vector $p_{i}$ are independent of each other. This assumption is violated, for example, in the realistic situation where the study material tested in the entrance examinations of several programs partly overlap.

While these limitations are real, they should affect the measurement of the application portfolios of the treatment and the control groups in a similar way. Thus we consider the issues primarily as measurement error in the outcome variable, which should not bias our estimates (but will make them less precise). 


\section{Additional results}

Table C.1: Applications by fields: 2012-2013 (year after graduation)

\begin{tabular}{|c|c|c|c|c|c|c|}
\hline & \multicolumn{2}{|c|}{2012} & \multicolumn{2}{|c|}{2013} & \multicolumn{2}{|c|}{2013 vs. 2012} \\
\hline & $\begin{array}{c}\text { Control } \\
\text { (1) }\end{array}$ & $\begin{array}{c}\text { Treated } \\
(2)\end{array}$ & $\begin{array}{c}\text { Control } \\
\text { (3) }\end{array}$ & $\begin{array}{c}\text { Treated } \\
(4)\end{array}$ & $\begin{array}{l}\text { OR } \\
(5)\end{array}$ & $\begin{array}{c}\text { p-value } \\
(6)\end{array}$ \\
\hline \multicolumn{7}{|c|}{ A: Polytechnics } \\
\hline Humanities & 0.033 & 0.030 & 0.039 & 0.035 & 0.975 & 0.672 \\
\hline Arts & 0.028 & 0.027 & 0.026 & 0.023 & 0.933 & 0.314 \\
\hline Business & 0.114 & 0.115 & 0.129 & 0.137 & 1.045 & 0.283 \\
\hline Engineering & 0.072 & 0.074 & 0.074 & 0.073 & 0.952 & 0.346 \\
\hline Agriculture & 0.009 & 0.010 & 0.009 & 0.009 & 0.971 & 0.806 \\
\hline Nursing & 0.159 & 0.169 & 0.167 & 0.175 & 0.986 & 0.665 \\
\hline Services & 0.042 & 0.041 & 0.033 & 0.033 & 1.018 & 0.820 \\
\hline \multicolumn{7}{|c|}{ B: Universities } \\
\hline Education & 0.092 & 0.086 & 0.111 & 0.105 & 1.015 & 0.795 \\
\hline Arts & 0.015 & 0.013 & 0.016 & 0.012 & 0.851 & 0.062 \\
\hline Humanities & 0.085 & 0.083 & 0.078 & 0.078 & 1.020 & 0.680 \\
\hline Business & 0.061 & 0.061 & 0.064 & 0.060 & 0.938 & 0.201 \\
\hline Social sciences & 0.046 & 0.050 & 0.056 & 0.055 & 0.915 & 0.066 \\
\hline Psychology & 0.019 & 0.018 & 0.017 & 0.017 & 1.011 & 0.910 \\
\hline Law & 0.013 & 0.013 & 0.012 & 0.013 & 1.091 & 0.170 \\
\hline Natural sciences & 0.088 & 0.088 & 0.067 & 0.073 & 1.078 & 0.176 \\
\hline Engineering & 0.066 & 0.063 & 0.042 & 0.039 & 0.976 & 0.749 \\
\hline Ind. management & 0.009 & 0.009 & 0.006 & 0.007 & 1.185 & 0.113 \\
\hline Architecture & 0.007 & 0.005 & 0.007 & 0.006 & 1.086 & 0.497 \\
\hline Agriculture & 0.004 & 0.004 & 0.004 & 0.005 & 0.995 & 0.973 \\
\hline Medicine & 0.017 & 0.018 & 0.018 & 0.018 & 0.959 & 0.348 \\
\hline Other health care & 0.011 & 0.012 & 0.013 & 0.013 & 0.950 & 0.572 \\
\hline Services & 0.010 & 0.010 & 0.014 & 0.014 & 0.966 & 0.688 \\
\hline Applications & 44,956 & 14,971 & 43,644 & 14,889 & 118,460 & \\
\hline
\end{tabular}

Note: Columns 1 to 4 report the distribution of applications from the treatment and control highschools in 2012 and 2013 among students graduating the previous year. Column 5 reports odds ratios for the change between years 2012 and 2013 by treatment status. Column 6 reports p-values for the odds ratios using randomization inference (see the text for discussion). The randomization inference p-value for testing homogeneity of odds-ratios is 0.533 . 
Table C.2: Cross-sectional estimates for the effect of the information on enrollment and application portfolios

\begin{tabular}{|c|c|c|c|c|c|c|c|}
\hline & \multirow[b]{2}{*}{ Dependent variable } & \multicolumn{3}{|c|}{ Year of graduation } & \multicolumn{3}{|c|}{ Year after graduation } \\
\hline & & $\begin{array}{l}\text { All } \\
(1)\end{array}$ & $\begin{array}{l}\text { Men } \\
(2)\end{array}$ & $\begin{array}{c}\text { Women } \\
(3)\end{array}$ & $\begin{array}{l}\text { All } \\
(4)\end{array}$ & $\begin{array}{c}\text { Men } \\
(5)\end{array}$ & $\begin{array}{c}\text { Women } \\
\quad(6)\end{array}$ \\
\hline (A) & Enrolled & $\begin{array}{l}-0.003 \\
(0.009) \\
{[0.740]}\end{array}$ & $\begin{array}{l}-0.008 \\
(0.012) \\
{[0.552]}\end{array}$ & $\begin{array}{c}0.002 \\
(0.010) \\
{[0.893]}\end{array}$ & $\begin{array}{l}-0.015 \\
(0.008) \\
{[0.121]}\end{array}$ & $\begin{array}{l}-0.015 \\
(0.012) \\
{[0.285]}\end{array}$ & $\begin{array}{l}-0.015 \\
(0.010) \\
{[0.190]}\end{array}$ \\
\hline (B) & $\begin{array}{l}\text { log Average earnings } \\
\text { in the program } \\
\text { where enrolled }\end{array}$ & $\begin{array}{l}-0.002 \\
(0.006) \\
{[0.862]}\end{array}$ & $\begin{array}{l}-0.006 \\
(0.006) \\
{[0.359]}\end{array}$ & $\begin{array}{c}0.004 \\
(0.007) \\
{[0.618]}\end{array}$ & $\begin{array}{l}-0.009 \\
(0.007) \\
{[0.276]}\end{array}$ & $\begin{array}{l}-0.009 \\
(0.007) \\
{[0.321]}\end{array}$ & $\begin{array}{l}-0.009 \\
(0.008) \\
{[0.288]}\end{array}$ \\
\hline (C) & $\begin{array}{l}\text { Average employment } \\
\text { rate in the program } \\
\text { where enrolled }\end{array}$ & $\begin{array}{l}-0.001 \\
(0.001) \\
{[0.727]}\end{array}$ & $\begin{array}{l}-0.001 \\
(0.001) \\
{[0.628]}\end{array}$ & $\begin{array}{l}0.000 \\
(0.001) \\
{[0.958]}\end{array}$ & $\begin{array}{l}-0.001 \\
(0.001) \\
{[0.595]}\end{array}$ & $\begin{array}{l}-0.001 \\
(0.002) \\
{[0.609]}\end{array}$ & $\begin{array}{l}-0.001 \\
(0.002) \\
{[0.598]}\end{array}$ \\
\hline (D) & $\begin{array}{l}\text { log Mean earnings } \\
\text { of the application } \\
\text { portfolio }\end{array}$ & $\begin{array}{l}-0.001 \\
(0.006) \\
{[0.879]}\end{array}$ & $\begin{array}{l}-0.006 \\
(0.006) \\
{[0.378]}\end{array}$ & $\begin{array}{c}0.003 \\
(0.006) \\
{[0.714]}\end{array}$ & $\begin{array}{l}-0.006 \\
(0.006) \\
{[0.446]}\end{array}$ & $\begin{array}{l}-0.010 \\
(0.006) \\
{[0.160]}\end{array}$ & $\begin{array}{l}-0.002 \\
(0.006) \\
{[0.740]}\end{array}$ \\
\hline (E) & $\begin{array}{l}\text { log Expected earnings } \\
\text { of the application } \\
\text { portfolio }\end{array}$ & $\begin{array}{l}-0.023 \\
(0.022) \\
{[0.397]}\end{array}$ & $\begin{array}{l}-0.026 \\
(0.026) \\
{[0.395]}\end{array}$ & $\begin{array}{l}-0.013 \\
(0.022) \\
{[0.631]}\end{array}$ & $\begin{array}{l}-0.006 \\
(0.018) \\
{[0.817]}\end{array}$ & $\begin{array}{l}-0.007 \\
(0.024) \\
{[0.828]}\end{array}$ & $\begin{array}{l}-0.005 \\
(0.020) \\
{[0.855]}\end{array}$ \\
\hline
\end{tabular}

Note: Cross-sectional ITT estimates, school-level clustered standard errors (in parantheses) and randomization inference p-values [in brackets] using 10,000 replications. Log expected value of the application portfolio is scaled to have a standard deviation of one. 
Table C.3: Full differences-in-differences estimates: everyone at the year of graduation

\begin{tabular}{|c|c|c|c|c|c|}
\hline & \multirow[b]{2}{*}{$\begin{array}{c}\text { Enrolled } \\
(1)\end{array}$} & \multicolumn{2}{|c|}{ Program where enrolled } & \multicolumn{2}{|c|}{ Application portfolio } \\
\hline & & $\begin{array}{c}\text { log Average } \\
\text { earnings } \\
(2)\end{array}$ & $\begin{array}{c}\text { Average emp- } \\
\text { loyment rate } \\
(3)\end{array}$ & $\begin{array}{c}\text { log Average } \\
\text { earnings } \\
(4)\end{array}$ & $\begin{array}{c}\log \text { Expected } \\
\text { earnings } \\
(5)\end{array}$ \\
\hline Treatment $\times$ post & $\begin{array}{c}-0.001 \\
(0.011)\end{array}$ & $\begin{array}{c}-0.012 \\
(0.007)\end{array}$ & $\begin{array}{c}-0.003 \\
(0.002)\end{array}$ & $\begin{array}{c}-0.002 \\
(0.006)\end{array}$ & $\begin{array}{c}0.019 \\
(0.024)\end{array}$ \\
\hline Treatment & $\begin{array}{l}-0.015 \\
(0.005)\end{array}$ & $\begin{array}{c}0.010 \\
(0.004)\end{array}$ & $\begin{array}{c}0.002 \\
(0.001)\end{array}$ & $\begin{array}{c}0.012 \\
(0.003)\end{array}$ & $\begin{array}{l}-0.005 \\
(0.013)\end{array}$ \\
\hline Post & $\begin{array}{l}-0.003 \\
(0.010)\end{array}$ & $\begin{array}{c}0.004 \\
(0.007)\end{array}$ & $\begin{array}{c}0.001 \\
(0.002)\end{array}$ & $\begin{array}{c}0.000 \\
(0.006)\end{array}$ & $\begin{array}{l}-0.028 \\
(0.024)\end{array}$ \\
\hline Constant & $\begin{array}{c}0.449 \\
(0.005)\end{array}$ & $\begin{array}{c}8.017 \\
(0.004)\end{array}$ & $\begin{array}{c}0.911 \\
(0.001)\end{array}$ & $\begin{array}{c}7.961 \\
(0.004)\end{array}$ & $\begin{array}{c}5.961 \\
(0.012)\end{array}$ \\
\hline $\mathrm{N}$ & 41,917 & 18,464 & 18,464 & 41,917 & 16,374 \\
\hline
\end{tabular}

Note: Differences-in-differences ITT estimates and school-level clustered standard errors. The specification also includes strata fixed-effects.

Table C.4: Full differences-in-differences estimates: everyone at the year after graduation

\begin{tabular}{|c|c|c|c|c|c|}
\hline & \multirow[b]{2}{*}{$\begin{array}{c}\text { Enrolled } \\
(1)\end{array}$} & \multicolumn{2}{|c|}{ Program where enrolled } & \multicolumn{2}{|c|}{ Application portfolio } \\
\hline & & $\begin{array}{c}\text { log Average } \\
\text { earnings } \\
(2)\end{array}$ & $\begin{array}{l}\text { Average emp- } \\
\text { loyment rate } \\
(3)\end{array}$ & $\begin{array}{c}\text { log Average } \\
\text { earnings } \\
(4)\end{array}$ & $\begin{array}{l}\text { log Expected } \\
\text { earnings } \\
(5)\end{array}$ \\
\hline Treatment $\times$ post & $\begin{array}{c}0.010 \\
(0.017)\end{array}$ & $\begin{array}{l}-0.002 \\
(0.011)\end{array}$ & $\begin{array}{l}-0.003 \\
(0.002)\end{array}$ & $\begin{array}{c}0.004 \\
(0.006)\end{array}$ & $\begin{array}{l}-0.004 \\
(0.028)\end{array}$ \\
\hline Treatment & $\begin{array}{l}-0.037 \\
(0.007)\end{array}$ & $\begin{array}{c}0.002 \\
(0.005)\end{array}$ & $\begin{array}{c}0.001 \\
(0.001)\end{array}$ & $\begin{array}{c}0.005 \\
(0.003)\end{array}$ & $\begin{array}{l}-0.022 \\
(0.015)\end{array}$ \\
\hline Post & $\begin{array}{l}-0.020 \\
(0.012)\end{array}$ & $\begin{array}{l}-0.008 \\
(0.008)\end{array}$ & $\begin{array}{c}0.000 \\
(0.002)\end{array}$ & $\begin{array}{l}-0.008 \\
(0.007)\end{array}$ & $\begin{array}{c}0.000 \\
(0.022)\end{array}$ \\
\hline Constant & $\begin{array}{c}0.430 \\
(0.005) \\
\end{array}$ & $\begin{array}{c}7.976 \\
(0.004) \\
\end{array}$ & $\begin{array}{c}0.906 \\
(0.001) \\
\end{array}$ & $\begin{array}{c}7.951 \\
(0.004)\end{array}$ & $\begin{array}{c}5.770 \\
(0.012)\end{array}$ \\
\hline $\mathrm{N}$ & 27,516 & 11,213 & 11,213 & 27,516 & 9,969 \\
\hline
\end{tabular}

Note: Differences-in-differences ITT estimates and school-level clustered standard errors. The specification also includes strata fixed-effects. 
Table C.5: Regression of negative surprises on matriculation exam choices and school characteristics

\begin{tabular}{lcc}
\hline & $(1)$ & $(2)$ \\
\hline Female & 0.0437 & 0.0366 \\
Advanced mathematics & $(0.0251)$ & $(0.0261)$ \\
Lutheran & -0.0360 & -0.0334 \\
& $(0.0286)$ & $(0.0297)$ \\
Orthodox & 0.0150 & 0.0199 \\
& $(0.0440)$ & $(0.0465)$ \\
Ethics & -0.275 & -0.382 \\
Philosophy & $(0.391)$ & $(0.418)$ \\
& -0.252 & -0.210 \\
Psychology & $(0.196)$ & $(0.199)$ \\
History & -0.00584 & -0.0119 \\
Physics & $(0.0608)$ & $(0.0623)$ \\
Chemistry & 0.0388 & 0.0427 \\
Biology & $(0.0295)$ & $(0.0311)$ \\
Geography & -0.0970 & -0.0818 \\
Health education & $(0.0315)$ & $(0.0326)$ \\
Social science & -0.0615 & -0.0748 \\
School bl. median & $(0.0368)$ & $(0.0385)$ \\
Controls for other school characteristics & -0.00744 & 0.00831 \\
Constant & $(0.0353)$ & $(0.0366)$ \\
& 0.230 & 4.274 \\
Observations & $(0.0361)$ & $(6.634)$ \\
\hline R-squared & 1,272 & 1,265 \\
\hline & 0.00439 & 0.00244 \\
& $(0.0310)$ & $(0.0323)$ \\
& -0.0116 & -0.0148 \\
& $(0.0346)$ & $(0.0362)$ \\
& -0.00424 & -0.0165 \\
& $(0.0274)$ & $(0.0291)$ \\
& -0.0588 & -0.0572 \\
& $(0.0302)$ & $(0.0312)$ \\
& -0.0697 & -0.116 \\
& & \\
& $0.0343)$ & $(0.123)$ \\
& & \\
& & \\
& &
\end{tabular}

Note: Dependent variable is an indicator for survey response that the average wage of the field where the respondent was thinking of applying is less than (s)he expected. Explanatory variables are dummy variables that take value one if the respondent took the subject in the matriculation exam (except for School bl. median which takes value one if the average matriculation grade of the school was below median). Controls for other school characteristics include shares of ap $\$$ ications from the school by field, shares of students who took the entrance exam by field, shares of students who were accepeted by field, and shares of students who were enrolled by field. We use results from column (1) to predict negative surprises in the rest of the population. School-level clustered standard errors are reported in parantheses. 
Table C.6: The effect of the information intervention by groups of predicted negative surprises

\begin{tabular}{|c|c|c|c|c|c|c|}
\hline & \multirow[b]{2}{*}{ Dependent variable } & \multicolumn{5}{|c|}{ Predicted likelihood of being negatively surprised } \\
\hline & & $\begin{array}{l}\text { (lowest) } \\
\text { Group } 1 \\
\quad(1)\end{array}$ & $\begin{array}{c}\text { Group } 2 \\
(2)\end{array}$ & $\begin{array}{c}\text { Group } 3 \\
(3)\end{array}$ & $\begin{array}{c}\text { Group } 4 \\
(4)\end{array}$ & $\begin{array}{l}\text { (highest) } \\
\text { Goup } 5 \\
(5)\end{array}$ \\
\hline$(\mathrm{A})$ & Enrolled & $\begin{array}{l}-0.032 \\
(0.034) \\
{[0.335]}\end{array}$ & $\begin{array}{c}0.037 \\
(0.024) \\
{[0.054]}\end{array}$ & $\begin{array}{l}-0.020 \\
(0.019) \\
{[0.187]}\end{array}$ & $\begin{array}{c}0.009 \\
(0.018) \\
{[0.601]}\end{array}$ & $\begin{array}{c}0.084 \\
(0.060) \\
{[0.134]}\end{array}$ \\
\hline (B) & $\begin{array}{l}\text { log Average earnings } \\
\text { in the program } \\
\text { where enrolled }\end{array}$ & $\begin{array}{l}-0.024 \\
(0.023) \\
{[0.172]}\end{array}$ & $\begin{array}{l}-0.024 \\
(0.012) \\
{[0.028]}\end{array}$ & $\begin{array}{l}-0.016 \\
(0.012) \\
{[0.133]}\end{array}$ & $\begin{array}{l}0.026 \\
(0.014) \\
{[0.016]}\end{array}$ & $\begin{array}{c}0.099 \\
(0.077) \\
{[0.060]}\end{array}$ \\
\hline$(\mathrm{C})$ & $\begin{array}{l}\text { Average employment } \\
\text { rate in the program } \\
\text { where enrolled }\end{array}$ & $\begin{array}{l}-0.008 \\
(0.005) \\
{[0.052]}\end{array}$ & $\begin{array}{l}-0.003 \\
(0.004) \\
{[0.437]}\end{array}$ & $\begin{array}{l}-0.005 \\
(0.005) \\
{[0.200]}\end{array}$ & $\begin{array}{c}0.011 \\
(0.008) \\
{[0.079]}\end{array}$ & $\begin{array}{c}0.041 \\
(0.041) \\
{[0.144]}\end{array}$ \\
\hline (D) & $\begin{array}{l}\text { log Mean earnings } \\
\text { of the application } \\
\text { portfolio }\end{array}$ & $\begin{array}{l}-0.019 \\
(0.017) \\
{[0.179]}\end{array}$ & $\begin{array}{l}-0.003 \\
(0.009) \\
{[0.789]}\end{array}$ & $\begin{array}{l}0.004 \\
(0.008) \\
{[0.647]}\end{array}$ & $\begin{array}{l}0.010 \\
(0.007) \\
{[0.111]}\end{array}$ & $\begin{array}{c}0.073 \\
(0.020) \\
{[0.000]}\end{array}$ \\
\hline$(\mathrm{E})$ & $\begin{array}{l}\text { log Expected earnings } \\
\text { of the application } \\
\text { portfolio }\end{array}$ & $\begin{array}{l}-0.128 \\
(0.074) \\
{[0.076]}\end{array}$ & $\begin{array}{c}0.066 \\
(0.040) \\
{[0.109]}\end{array}$ & $\begin{array}{c}0.076 \\
(0.043) \\
{[0.037]}\end{array}$ & $\begin{array}{c}0.017 \\
(0.042) \\
{[0.644]}\end{array}$ & $\begin{array}{c}0.269 \\
(0.146) \\
{[0.036]}\end{array}$ \\
\hline $\begin{array}{l}\text { Obs } \\
\text { Obs } \\
\text { ditic }\end{array}$ & $\begin{array}{l}\text { rvations (full) } \\
\text { rvations (con- } \\
\text { nal on enrollment) }\end{array}$ & $\begin{array}{l}4,328 \\
2,340\end{array}$ & $\begin{array}{c}11,568 \\
6,490\end{array}$ & $\begin{array}{c}13,188 \\
5,660\end{array}$ & $\begin{array}{c}12,136 \\
3,825\end{array}$ & $\begin{array}{l}697 \\
149\end{array}$ \\
\hline $\begin{array}{l}\text { Note } \\
\text { ses) } \\
\text { inter }\end{array}$ & ifferences-in-differences IT & . & nool-level & astered sta & lard errors & $\begin{array}{l}\text { In paranthe- } \\
\text { information }\end{array}$ \\
\hline
\end{tabular}


Table C.7: The effect of the information intervention by groups of predicted negative surprises

\begin{tabular}{|c|c|c|c|c|c|c|}
\hline & \multirow[b]{2}{*}{ Dependent variable } & \multicolumn{5}{|c|}{ Predicted likelihood of being negatively surprised } \\
\hline & & $\begin{array}{l}\text { (lowest) } \\
\text { Group } 1 \\
(1)\end{array}$ & $\begin{array}{c}\text { Group } 2 \\
(2)\end{array}$ & $\begin{array}{c}\text { Group } 3 \\
(3)\end{array}$ & $\begin{array}{c}\text { Group } 4 \\
(4)\end{array}$ & $\begin{array}{l}\text { (highest) } \\
\text { Goup } 5 \\
(5)\end{array}$ \\
\hline (A) & Enrolled & $\begin{array}{l}-0.013 \\
(0.024) \\
{[0.560]}\end{array}$ & $\begin{array}{c}0.028 \\
(0.024) \\
{[0.190]}\end{array}$ & $\begin{array}{l}-0.015 \\
(0.025) \\
{[0.410]}\end{array}$ & $\begin{array}{l}-0.015 \\
(0.024) \\
{[0.470]}\end{array}$ & $\begin{array}{c}0.019 \\
(0.024) \\
{[0.380]}\end{array}$ \\
\hline (B) & $\begin{array}{l}\text { log Average earnings } \\
\text { in the program } \\
\text { where enrolled }\end{array}$ & $\begin{array}{l}-0.024 \\
(0.015) \\
{[0.070]}\end{array}$ & $\begin{array}{l}-0.016 \\
(0.016) \\
{[0.270]}\end{array}$ & $\begin{array}{l}-0.028 \\
(0.016) \\
{[0.010]}\end{array}$ & $\begin{array}{l}-0.001 \\
(0.017) \\
{[0.970]}\end{array}$ & $\begin{array}{c}0.030 \\
(0.017) \\
{[0.020]}\end{array}$ \\
\hline (C) & $\begin{array}{l}\text { Average employment } \\
\text { rate in the program } \\
\text { where enrolled }\end{array}$ & $\begin{array}{l}-0.006 \\
(0.004) \\
{[0.090]}\end{array}$ & $\begin{array}{l}-0.003 \\
(0.005) \\
{[0.470]}\end{array}$ & $\begin{array}{l}-0.007 \\
(0.006) \\
{[0.110]}\end{array}$ & $\begin{array}{l}-0.003 \\
(0.008) \\
{[0.570]}\end{array}$ & $\begin{array}{l}0.022 \\
(0.009) \\
{[0.000]}\end{array}$ \\
\hline (D) & $\begin{array}{l}\text { log Mean earnings } \\
\text { of the application } \\
\text { portfolio }\end{array}$ & $\begin{array}{l}-0.018 \\
(0.011) \\
{[0.140]}\end{array}$ & $\begin{array}{l}0.006 \\
(0.011) \\
{[0.530]}\end{array}$ & $\begin{array}{c}0.001 \\
(0.009) \\
{[0.930]}\end{array}$ & $\begin{array}{c}0.009 \\
(0.009) \\
{[0.330]}\end{array}$ & $\begin{array}{c}0.010 \\
(0.008) \\
{[0.140]}\end{array}$ \\
\hline$(\mathrm{E})$ & $\begin{array}{l}\text { log Expected earnings } \\
\text { of the application } \\
\text { portfolio }\end{array}$ & $\begin{array}{l}-0.075 \\
(0.047) \\
{[0.090]}\end{array}$ & $\begin{array}{l}0.103 \\
(0.049) \\
{[0.010]}\end{array}$ & $\begin{array}{l}0.103 \\
(0.054) \\
{[0.020]}\end{array}$ & $\begin{array}{l}0.021 \\
(0.051) \\
{[0.580]}\end{array}$ & $\begin{array}{l}0.025 \\
(0.049) \\
{[0.560]}\end{array}$ \\
\hline \multicolumn{2}{|c|}{$\begin{array}{l}\text { Observations (full) } \\
\text { Observations (con- } \\
\text { ditional on enrollment) }\end{array}$} & $\begin{array}{l}8,658 \\
4,808\end{array}$ & $\begin{array}{l}8,476 \\
4,583\end{array}$ & $\begin{array}{l}8,297 \\
3,634\end{array}$ & $\begin{array}{l}8,220 \\
3,024\end{array}$ & $\begin{array}{l}8,266 \\
2,415\end{array}$ \\
\hline \multicolumn{7}{|c|}{$\begin{array}{l}\text { Note: Differences-in-differences ITT estimates, school-level clustered standard errors (in paranthe- } \\
\text { ses) and randomization inference p-values [in brackets] using 10,000 replications of the information } \\
\text { intervention. Groups are defined by predicted surprises based on the results in Table C.5. Group } \\
1 \text { has the lowest predicted surprise and group } 5 \text { the highest. }\end{array}$} \\
\hline
\end{tabular}


Table C.8: The effect of the information intervention by groups of predicted negative surprises: linear specification

\begin{tabular}{|c|c|c|c|c|c|}
\hline & \multirow[b]{2}{*}{$\begin{array}{l}\text { Enrolled } \\
\quad(1)\end{array}$} & \multicolumn{2}{|c|}{ Program where enrolled } & \multicolumn{2}{|c|}{ Application portfolio } \\
\hline & & $\begin{array}{l}\log \text { Average } \\
\text { earnings } \\
(2)\end{array}$ & $\begin{array}{l}\text { Average emp- } \\
\text { loyment rate } \\
\text { (3) }\end{array}$ & $\begin{array}{c}\text { log Average } \\
\text { earnings } \\
(4)\end{array}$ & $\begin{array}{c}\log \text { Expected } \\
\text { earnings } \\
(5)\end{array}$ \\
\hline $\begin{array}{l}\text { Treatment } \times \\
\text { post }\end{array}$ & $\begin{array}{l}-0.018 \\
(0.030) \\
{[0.456]}\end{array}$ & $\begin{array}{l}-0.044 \\
(0.018) \\
{[0.002]}\end{array}$ & $\begin{array}{l}-0.013 \\
(0.006) \\
{[0.003]}\end{array}$ & $\begin{array}{l}-0.028 \\
(0.012) \\
{[0.019]}\end{array}$ & $\begin{array}{l}-0.049 \\
(0.054) \\
{[0.382]}\end{array}$ \\
\hline $\begin{array}{l}\text { Predicted } \\
\text { surprise }\end{array}$ & $\begin{array}{l}-1.235 \\
(0.052)\end{array}$ & $\begin{array}{l}-1.487 \\
(0.034)\end{array}$ & $\begin{array}{l}-0.251 \\
(0.012)\end{array}$ & $\begin{array}{l}-1.375 \\
(0.027)\end{array}$ & $\begin{array}{l}-3.515 \\
(0.118)\end{array}$ \\
\hline $\begin{array}{l}\text { Treatment } \times \\
\text { post } \times \\
\text { predicted surprise }\end{array}$ & $\begin{array}{c}0.094 \\
(0.131) \\
{[0.382]}\end{array}$ & $\begin{array}{c}0.177 \\
(0.088) \\
{[0.012]}\end{array}$ & $\begin{array}{c}0.062 \\
(0.032) \\
{[0.013]}\end{array}$ & $\begin{array}{c}0.142 \\
(0.051) \\
{[0.007]}\end{array}$ & $\begin{array}{c}0.402 \\
(0.253) \\
{[0.098]}\end{array}$ \\
\hline $\mathrm{N}$ & 41,917 & 18,464 & 18,464 & 41,917 & 40,692 \\
\hline
\end{tabular}

Note: Differences-in-differences ITT estimates, school-level clustered standard errors (in parantheses) and randomization inference p-values [in brackets] using 10,000 replications of the information intervention. The regression also includes main effects for treatment and post as well as interaction terms for treatment $\times$ predicted surprise and post $\times$ predicted surprise. 


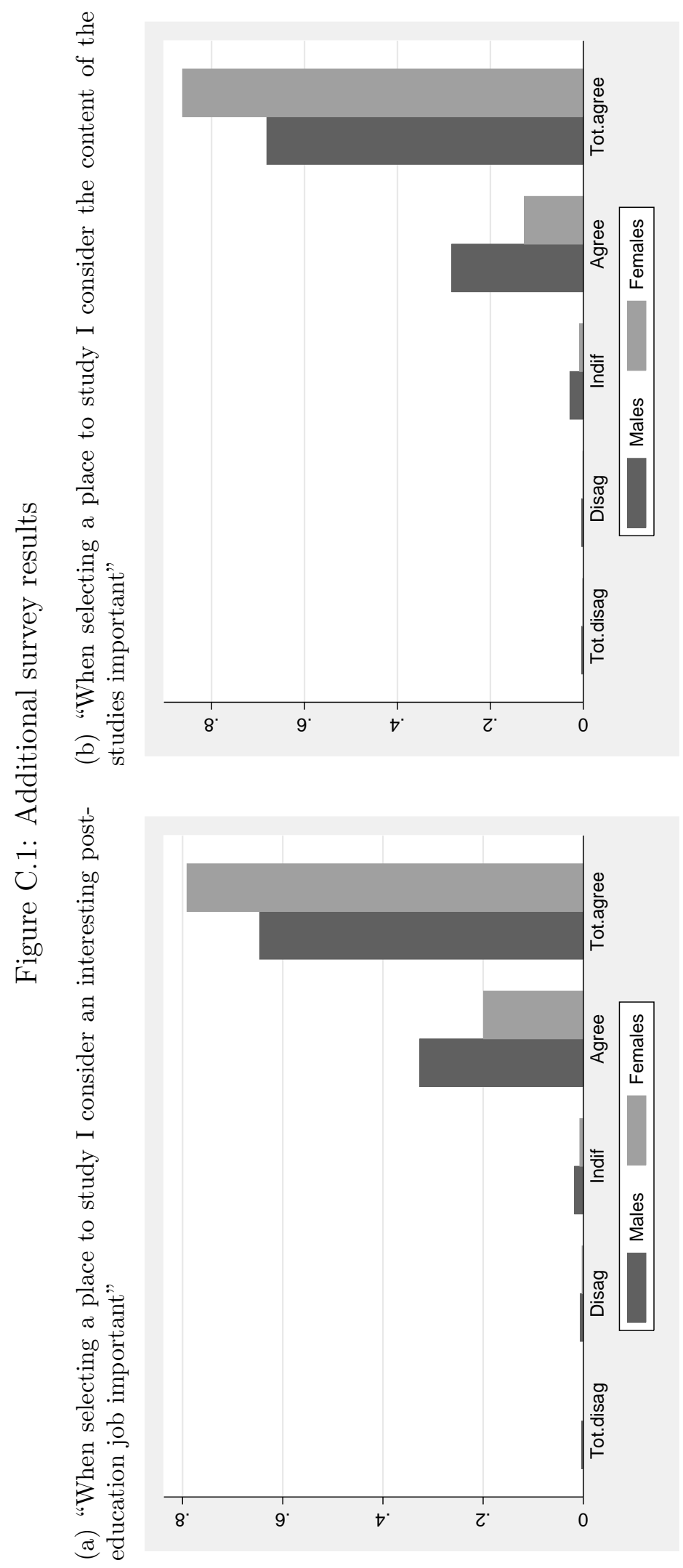

